Ownership: Evolution and Regulation

\author{
Julian Franks \\ Professor of Finance, London Business School
}

Colin Mayer

Peter Moores Professor of Management Studies, Saïd Business School, University of Oxford

\author{
Stefano Rossi
}

London Business School

25 March 2005

We are grateful for helpful suggestions from participants at conferences at the American Finance Association meetings in Washington DC, January 2003, the National Bureau of Economic Research Programme on the Evolution of Family Ownership conference in Boston, INSEAD and Lake Louise, the Political Economy of Financial Markets Conference at Princeton, September 2003, the RIETI Conference on Comparative Corporate Governance: Changing Profiles of National Diversity in Tokyo, January 2003, the NBER Summer Institute Corporate Finance Workshop 2004, the Western Finance Association meetings in Vancouver, June 2004, the European Finance Association meetings in Maastricht, August 2004, and at seminars at the Bank of England, the Bank of Italy, Cambridge University, the London Business School, the London School of Economics, SNS, Stockholm, the Stern School, New York University, Université Libre de Bruxelles, University of Bologna and UCLA. We have received helpful comments from Brian Cheffins, Barry Eichengreen, Nadja Guenster, Charles Hadlock, Leslie Hannah, Oliver Hart, Cliff Holderness, Gregory Jackson, Kose John, Hideaki Miyajima, Randall Morck, Mark Roe, David Scharfstein, Hyun Song Shin, Jeremy Stein, Oren Sussman, Elu von Thadden, Xavier Vives, Ralph Walkling and Yishay Yafeh. Shamoon Chaudry, Raju Chinthalapati, and Lisa Lernborg provided excellent research assistance. 


\title{
Ownership: Evolution and Regulation
}

\begin{abstract}
This paper is the first study of long-run evolution of investor protection, equity financing and corporate ownership in the U.K. over the $20^{\text {th }}$ century. Formal regulation only emerged in the second half of the century. We assess its influence on finance and ownership by comparing evolution of firms incorporating at different stages of the century. Regulation had little impact on equity issues or dispersion of ownership: even in the absence of regulation, there was a large amount of both, primarily associated with mergers. The main effect of regulation was on share trading and the market for corporate control. Financial development in the UK relied more on informal relations of trust than on formal systems of regulation. Preliminary evidence on this comes from the geographical proximity of shareholders to their boards of directors, the absence of price discrimination in takeovers and retention of directors of target boards in merged firms.
\end{abstract}

JEL Classification: G32, G34

Key words: Evolution, ownership, investor protection, equity issues, trust 


\section{Introduction}

One of the best-established stylised facts about corporate ownership is that ownership of large listed companies is dispersed in the U.K. and U.S. and concentrated in most other countries. For example, Becht and Mayer (2001) report that in more than $50 \%$ of European companies there is a single voting block of shareholders that commands a majority of shares. In contrast, in the U.K. and U.S. it is less than $3 \%$.

There are two prominent theories of regulation and law that have been proposed to explain these differences. The first attributable to Mark Roe (1994) is that U.S. legislators responded to a populist agenda in the 1930's by limiting the power exercised by large financial conglomerates. This was accomplished by introducing legislation that restricted the control rights of large blockholders. The second, associated with La Porta, Lopez-de-Silanes, Shleifer and Vishny (1997 and 1998, LLSV henceforth), argues that concentrated ownership is a response to inadequate regulation. According to their view, in the absence of adequate protection, investors seek to protect their investments with the direct exercise of control through large share blocks. Concentrated ownership is therefore a response to deficient investor protection.

In both these law and finance theories dispersed ownership is associated with strong regulation. The difference in ownership concentrations in the U.K. and the U.S. on the one hand and Continental Europe on the other can be attributed to weak regulation in Continental Europe and strong regulation in the U.K. and U.S. LLSV produce data to support this conclusion. They distinguish between the common law systems of the U.K. and U.S. and the civil law systems in Continental Europe. They show that common law systems have strong minority investor protection and civil law systems have weak protection.

According to the law and finance literature, differences in legal structures are deep rooted with a long history. One would therefore expect differences in investor protection also to have a long history. But this is not the case, at least for the U.K. At the beginning of the century, the U.K. was devoid of anti-director rights provisions and protection of small investors. According to LLSV measure of anti-director rights, the U.K. only scored one out of a maximum of six between 1900 and 1946 - on a par with Germany in the early 1990s. Even on broader based measures of disclosure, liability standards for directors and public enforcement proposed by La Porta, Lopez-de-Silanes, and Shleifer (2004, LLS henceforth), investor protection in the first three decades of the century was very weak. 
Common law contributed to this: in 1843 there was a landmark case of unsuccessful litigation by an injured investor in the U.K. (Foss vs. Harbottle) that undermined the rights of minority investors to seek protection through the courts for more than a century. This principle was upheld in subsequent cases, and the leading British company law academic, Leonard Sealy, observed that, "the courts have made it very difficult, and in many cases impossible, for shareholders with grievances sometimes, shareholders who are the victims of very real injustices - to obtain a legal remedy." (Sealy (1984, p. 53)).

If investor protection at the beginning of the century in the U.K. was on a par with Germany today then this raises the question of whether capital markets in the U.K. bore closer resemblance to Germany than the U.K. today. The law and finance literature would predict that, in the first half of the century, the U.K. would have relatively undeveloped financial markets, minority investor abuse and high concentrations of ownership. As Cheffins (2002) has noted, unlike in the U.S., there was no legislation in the U.K. during the $20^{\text {th }}$ century discouraging concentrations of shareholdings in the hands of financial institutions or other investors so that, if any law and finance theory is relevant to the U.K., it is the LLSV rather than the Mark Roe version.

A second interesting feature of investor protection in the U.K. is the degree to which it was strengthened during the century. By the end of the century, the LLSV measure of anti-director rights had increased from one to five out of the maximum of six. In addition, there were aspects of investor protection not captured by the LLSV index that were introduced from the middle of the century, for example rules concerning removal of directors. According to the law and finance literature, we would therefore predict a significant increase in the rate of dispersion of ownership in the second half of the century.

We address these questions by looking at the evolution of ownership of 60 U.K. firms over the twentieth century. Several studies (for example, Berle and Means (1932), Florence (1961), Holderness, Kroszner and Sheehan (1999), Larner (1966) and Nyman and Silberston (1978)) report statistics on the ownership of cross-sections of firms in the U.K. and U.S. at different points in time. But no study to date has examined how ownership of a panel of firms has evolved over an extended period - a hundred years in the case of this study - and to establish what factors have contributed to that evolution. 
That is precisely what this paper attempts to do. It has been made possible by the existence of an unusually rich source of data in the U.K. For more than a century, Parliament has required companies to deposit information, including accounts and a register of shareholders, at a central depository open to the public. From this depository, we select three samples of firms, one from companies incorporated around the turn of the century that have been in continuous existence since then, a second from firms incorporated at the same time but which are no longer in existence today and a third from companies incorporated around 1960 and still in existence today. We develop a new methodology to trace their share ownership over time and analyze the influence of regulation on this.

We find that the U.K. had a vibrant capital market at the beginning of the century. There were a large number of companies actively traded on stock markets around the country. According to Rajan and Zingales (2003), measured by market capitalization relative to GDP, the U.K. had the second largest stock market in the world, surpassed only by Cuba!

Furthermore, there was a high level of equity issuance at the beginning of the century. The average rate of growth of issued equity in our sample of firms that were incorporated around 1900 was $10.8 \%$ per annum over the period 1900 to 1940 . Most of that growth $(87 \%)$ was associated with equity issued for share exchanges and cash raised specifically for acquisitions and mergers.

Not only was the large amount of equity issuance an indicator of a thriving U.K. equity market, but it was also the underlying cause of another striking development. Ownership of the sample of U.K. firms incorporated around 1900 was rapidly dispersed with the shareholdings of inside directors more than halving over the 40 years to 1940 . The differences in ownership concentration between the U.K. and Continental European countries today are not a recent phenomenon - dispersed ownership emerged rapidly in the first half of the $20^{\text {th }}$ century, even in the absence of strong investor protection. The most significant cause of this was acquisitions and mergers. Shares issued in the process of equity exchanges diluted the ownership stakes of existing shareholders.

When investor protection was finally strengthened in the second half of the century, it had little effect on either equity issuance or rates of ownership dispersion. Ownership of well-established companies was already dispersed and rates of dispersion 
of newly incorporated firms, for example of the sample of firms incorporated around 1960, were similar to those of firms incorporated at the start of the century.

An obvious question that this raises is how large-scale equity issuance and ownership dispersion could have occurred in the absence of investor protection. We suggest that trust and informal relations played an important part and we illustrate their role in the process of issuing equity for acquisitions and mergers. In principle, bidding companies could have acquired targets at low cost by making discriminatory offers to selected shareholders and purchasing the minimum shareholding required to secure control. This was commonplace in Germany until recently (see Jenkinson and Ljungqvist (2001) and Franks and Mayer (2001)). But what was observed in the U.K. in the first half of the century was quite different. Offers were made without discrimination at equal prices to all shareholders. Directors of target firms played an important role in upholding this equal price convention by stating publicly whether they intended to tender their own shareholdings at the offer price and making recommendations to their shareholders to follow their example. We also provide evidence on the importance of proximity of shareholders to boards of directors and the promotion of directors of target firms to the boards of merging firms.

Investor protection was not therefore a necessary condition for the emergence of active securities markets in the U.K. in the $20^{\text {th }}$ century. However, its introduction was associated with two developments. The first was a greater turnover of shareholdings. While rates of dispersion of ownership were similar in the first and second halves of the century, rates of turnover of large blocks of shareholdings by both insiders and outsiders were markedly higher in the second half. We measure this by looking at the composition of the smallest coalition of shareholders required to exercise control, and how the composition of that coalition changed over time; both of these measures are new and have distinct advantages over traditional metrics of ownership concentration. The average annual turnover of coalitions went up by a factor of about three between the first and second halves of the century for the samples of firms in this study. Stronger investor protection was associated with a more liquid market that allowed insiders to sell their shares to outside block holders. This in turn facilitated the rise of the institutional shareholdings that dominated the second half of the $20^{\text {th }}$ century.

The second and even more significant development was the emergence of a market in corporate control in the 1950's. The introduction of rules on accounting disclosure at the end of the 1940's provided the basis on which acquiring companies 
could for the first time estimate the value of target firms from publicly available sources of information. This allowed acquiring firms to bypass the board of directors and appeal directly to the target shareholders through a tender offer. This therefore upset the prevailing convention mentioned above whereby target directors controlled the takeover process and could ensure that all shareholders were offered equal prices for their shares. Instead, raiders accumulated blocks of shares at prices that discriminated between shareholders. The increase in liquidity and the emergence of a market for corporate control in the second half of the century may therefore have come at the expense of conventions based on trust. Regulation, in the form for example of a takeover code, was then required to substitute for a decline in trust.

In sum, the world's first common law system was not initially associated with strong formal investor protection. In many respects it was exceptionally weak. But this did not prevent it from having unusually large or active stock markets. In fact, the U.K. stock markets allowed firms to issue substantial amounts of equity to acquire and merge with other firms and thereby to set in motion the dispersion that distinguishes ownership in the U.K. today from other European countries. The trust relationships that we report in the U.K. may have been observed in other forms elsewhere. For example, Franks, Mayer and Wagner (2005) record a high level of equity finance in Germany in the early decades of the $20^{\text {th }}$ century. They find that banks played an important role in the new issue process by holding and voting shares at shareholder meetings as custodians of individual investors.

Section 2 of the paper discusses the law and finance thesis that we examine in this paper, the data and the methodology that we employ to test it. Section 3 documents the development of investor protection and securities markets in the U.K. in the $20^{\text {th }}$ century. Section 4 records the growth of issued equity in our sample of firms and how acquisitions contributed to it. Section 5 measures concentration of ownership of our sample of firms and the rates at which shareholdings were dispersed and shareholder coalitions changed at different points in the century. Section 6 provides preliminary evidence of the role of trust in U.K. capital markets at the beginning of the $20^{\text {th }}$ century as reflected in the proximity of shareholders to the firms in which they were invested, the absence of price discrimination in takeovers and the promotion of directors and chairmen of target firms to the boards of merged firms. Section 7 concludes the paper. 


\section{Theory, data and methodology}

\subsection{Theory}

According to LLSV, common law systems are associated with strong investor protection. Investor protection is a necessary condition for flourishing financial markets and is required to encourage a wide group of small investors to participate in stock markets. Without this, external financing of companies is limited. In the absence of strong investor protection in the U.K., there should have been little external equity financing in the first half of the $20^{\text {th }}$ century and more in the tougher investor protection climate of the second half of the century. As Rossi and Volpin (2004) note this should also be reflected in the medium of exchange used in acquisitions, with equity exchange offers being more acceptable to target shareholders with stronger investor protection in the second half of the century.

The law and finance literature links investor protection to the avoidance of abuse of minority investors. There are numerous forms that such abuse might take but one that attracts the attention of regulators is discriminatory pricing between large and small investors in major equity transactions. One of the most significant equity transactions is the acquisition of one company by another. In the absence of strong investor protection, minorities might be abused by being offered lower prices for their shares than large investors. Discriminatory pricing in takeovers is still a feature of many countries' takeover markets today. We might have expected it to feature in the takeover markets of the first half of the twentieth century when investor protection in the U.K. was weak. In addition, small investors might be expected to suffer in other equity issues if insiders or large outside investors can subscribe at below market prices.

According to LLSV, the threat of abuse discourages minority investors from participating in financial markets with poor investor protection. As a consequence, share ownership is highly concentrated in low investor protection regimes. Faced with weak investor protection at the beginning of the twentieth century, share ownership in the U.K. should therefore have been concentrated. This is clearly important in considering how the U.K. (and the U.S.) developed their distinctive patterns of dispersed share ownership. In the U.K., this should have been a relatively recent phenomenon coinciding with the emergence of strong investor protection in the second half of the $20^{\text {th }}$ century, at least as measured by LLSV. Moreover, given that investor protection in England at least pre-1948 was on a par with Germany in 1990, according 
to the LLSV index, we might expect to observe similar levels of concentration of ownership and low rates of dispersion.

\subsection{Data}

Since the beginning of the $20^{\text {th }}$ century, all U.K. firms have been required to file information at a central depository called Companies House in Cardiff, Wales. This is a unique long-run source of data on firms. However, it suffers from one deficiency: Companies House retains complete records on all firms that are still in existence today but sends information on dead companies to the Public Records Office in Kew, Richmond (Surrey). In turn, the Public Records Office has kept information on all companies dissolved before 1932, and on a random sample of companies dissolved thereafter. We therefore supplemented data from Companies House with this second source.

We collected data for two time periods: companies incorporated around 1900 and 1960. 1900 is the first date for which records on companies are available. 1960 corresponds to the date by which a regime shift has occurred and many of the legislative changes documented in this paper are in place. There were 20 firms that were incorporated or (re-) incorporated ${ }^{1}$ between 1897 and 1903 and still in existence in 2001 and 20 firms that were incorporated between 1958 and 1962 and were still in existence in 2001; we have collected data on all of these. To avoid the obvious bias that might arise from the greater longevity of the 1900 than the 1960 sample, we collected a second sample of firms incorporated around 1900 that are no longer in existence today. We impose a minimum life of 11 years on the non-surviving firms so that we have at least one complete decade of data on each. Panel A of Table A1 records that, of the 20 dead companies in the 1900 sample, three died before 1940, and 17 subsequently.

To establish the representativeness of our 1900 samples we compared them with two benchmarks. The first is the population of firms listed on the London Stock Exchange in 1900, as reported in the January issue of the Investors' Monthly Manual. ${ }^{2}$ Table A2 shows the size of the Stock Exchange in that year. It records that there were 1354 firms with a total market capitalization of just over $£ 1$ billion. Our sample is

\footnotetext{
${ }^{1}$ An important feature of both sub-samples is that many firms were in existence well before their incorporation. For example, Cadbury Schweppes was established in 1783, incorporated in 1886 and reincorporated in 1900; REA incorporated in 1889 as Ceylon Tea Plantations and reincorporated in 1960.

${ }^{2}$ Source of data: http://icf.som.yale.edu/imm/
} 
restricted to five sectors: breweries and distilleries, iron, coal and steel, steamship and shipbuilding, mining companies and other commercial and industrial companies. Between them, these account for $43 \%$ of market capitalization in 1900 . We exclude in particular utilities (railways, banking and financials) and foreign corporations. Since ownership is likely to be more dispersed in relatively safe utilities than in other sectors, their exclusion is likely to lead to an under- rather than an over-statement of dispersion of ownership.

Our sample represents $5 \%$ of the number of firms listed on the London Stock Exchange in 1900 in these five sectors and 3\% of market capitalization. There is much higher representation in iron, coal and steel $(12 \%$ by number and $11 \%$ by market capitalization) and lower representation in breweries and distilleries $(0.7 \%$ by number and $0.1 \%$ by market capitalization). We also compare our samples with a second benchmark, namely the number of newly listed firms in 1900 as reported in the 12 monthly issues of the Investors' Monthly Manual. Our sample represents just less than $30 \%$ of the number of new listings in the five sectors in 1900 with a higher representation of steamship and shipbuilding as well as iron, coal and steel companies and a lower representation of mining companies.

We report results for the 1900 samples of survivors and non-survivors separately and for the two together. There are therefore three bases of comparison with the 1960 sample in the tables reported below: survivors, non-survivors and the combined sample, which provides an average of the two. Which is the most appropriate depends on what proportion of the 1960 firms is expected to survive for at least a hundred years. If all do then the surviving sample is the most relevant; if none do, then the non-surviving sample should be used and if 50\% survive then the average is the closest benchmark. Since we are not currently in a position to answer this question we report results for all samples.

Company filings (the "annual returns") include information on names, addresses of shareholders, the size of their stake, and their occupation (e.g. "director of the company", “gentleman", “civil engineer", “spinster"). We collected additional information from: (i) new issue prospectuses in the Guildhall Library in London, (ii) annual issues of the Stock Exchange Year Book, which lists names of directors and the sources of any changes in issued capital, and (iii) official lists of trading of securities from the British Library in London. In addition, we consulted the share registers, which 
form part of the company's "annual returns", to provide evidence of ownership changes that have taken place on an annual basis.

From these data, we collect names of directors, their shareholdings (including those of their families), the date and amounts of capital issued in acquisitions, new share issues raised through public and private placements, and other changes in share capital, such as capitalization of reserves. We trace the founding family ownership from incorporation until the last family member left the board. We take account of name changes across generations, when for example the daughter of a founder married. We limit the recording of outside shareholdings to stakes greater than $1 \%$ of ordinary capital. We use newspaper archives to document evidence of mergers and tender offers, trading in shares on provincial Stock Exchanges, especially in the early 1900s. We collect share prices pre-1955 from the Daily Official List, published by the stock exchanges, and post-1955 from the London Business School share price database. Finally, to establish the proximity of shareholders to directors, we compute measures of distance of ordinary and preference shareholders from their private addresses to the address of the company's headquarters of twenty-six firms in 1910.

Table A1 in the Appendix lists the names of the companies, their city and date of incorporation, the date of their initial public offering (IPO), the stock exchanges on which their shares were traded, and their status as of 2001. Table A1 records that many companies were traded on local stock exchanges prior to a formal IPO. This reflects the absence of listing requirements for companies traded on these exchanges and the London Stock Exchange (LSE) in the first half of the century. Six out of 22 formal IPOs in the 1900 sample occurred in anticipation, or just after the introduction of more rigorous listing requirements by the LSE in 1947.

\subsection{Methodology}

The approach taken in this paper is to test the above theories against long-run evidence on the evolution of ownership and control of corporations in the U.K. We introduce two new measures of changes in ownership and control based on the work of Grossman and Hart (1986) and Hart and Moore (1990). We assume that when contracts are incomplete the residual control rights are associated with critical ownership thresholds, typically 25,50 or $75 \%$. We record the minimum size and composition of coalitions required to pass these thresholds at ten yearly intervals. The two new measures are first the rate at which ownership is dispersed, i.e. the change in the 
minimum number of shareholders required to cross the critical ownership threshold. The second is the change in the composition or membership of this smallest coalition, which we describe as "mutation" of ownership. It is the inverse of the stability of the membership of the smallest coalition and measures the rate at which the controlling shareholders change. In addition, we report standard measures of concentration of ownership, such as size of directors' shareholdings, C3, C5 and Herfindahl indices. We report both measures for three groups of investors: all shareholders and inside and outside shareholders separately.

The annual rate of dispersion, $\mathrm{d}$, from year $\mathrm{t}$ to $\mathrm{t}+\mathrm{T}$ is defined as:

$$
\mathrm{d}=\left\{\mathrm{Y}_{\mathrm{t}+\mathrm{T}} / \mathrm{Y}_{\mathrm{t}}\right\}^{1 / \mathrm{T}}-1
$$

where $\mathrm{Y}$ is ownership defined as the minimum number of shareholders required to pass the threshold of $25 \%, \mathrm{t}$ is the calendar date and $\mathrm{T}$ is the length of the measurement interval (10 years in our analysis). ${ }^{3}$ We also measure this at a $50 \%$ threshold. ${ }^{4}$

Mutation of ownership from year $\mathrm{t}$ to $\mathrm{t}+\mathrm{T}$ is defined as:

$$
\mathrm{m}=1-\left\{\mathrm{Z}_{\mathrm{t}+\mathrm{T}} / \mathrm{Z}_{\mathrm{t}}\right\}^{1 / \mathrm{T}}
$$

where $\mathrm{Z}_{\mathrm{t}+\mathrm{T}} / \mathrm{Z}_{\mathrm{t}}$ is the proportion of members of the ownership coalition in year $\mathrm{t}+\mathrm{T}$ who were present in year $\mathrm{t}^{5}$

This methodology provides the first measures of ownership based on control. Our measures may change when conventional indices of concentration do not, for example when the number or composition of owners alters but the size distribution of shareholders does not. As an illustration, if a large shareholder with $25 \%$ of stock sells

\footnotetext{
${ }^{3}$ The rate of dispersion, $\mathrm{d}$, for directors and outsiders is $100 \%$ if in period t they hold more than $25 \%$ and in period $\mathrm{t}+\mathrm{T}$ their holding declines below this threshold.

${ }^{4}$ At first sight, the fact that there is more than one definition of ownership corresponding to different values of $\mathrm{x}$ appears unsatisfactory. In fact, this is an important characteristic of ownership of a corporation as against a personal asset. Different groups have control over different actions - the $25 \%$ group has control over those issues that are subject to a blocking minority and the $50 \%$ group over those that are conditional on a simple as against a super-majority. Ownership of a corporation cannot be defined independently of the decisions over which control is exercised.

${ }^{5}$ One way to think about the relation between dispersion and mutation of ownership is as follows. Let the control threshold be defined as $\mathrm{x}$. The control group in period $\mathrm{t}$ is the smallest number of individuals $\mathrm{i}=1$ to $\mathrm{I}_{\mathrm{t}}$ such that:
}

$$
\sum_{i=1}^{I_{t}} \alpha_{i, t}=x
$$

where $\alpha_{i, t}$ is shareholding of individual i in period $t$.

Let $\mathrm{i}=1$ be the founding family then we can define dilution of their ownership between $\mathrm{t}$ and $\mathrm{t}+1$ as:

$$
\alpha_{1, t+1}-\alpha_{1, t}=-\sum_{i=I_{t}+1}^{I_{t+1}} \alpha_{i, t+1}-\left(\sum_{i=2}^{I_{t}} \alpha_{i, t+1}-\sum_{i=2}^{I_{t}} \alpha_{i, t}\right)
$$

The first term is related to dispersion through broadening of the control group and the second to mutation of the existing control group. New issues or sales of shares to new and existing shareholders can therefore dilute the founding family's ownership. 
to another new shareholder then control alters but concentration does not. Similarly, cash takeovers change composition but not necessarily concentration. Existing measures of size distribution (concentration ratios, Herfindahl indices, Gini coefficients etc) cannot capture these changes in composition.

Concentration may change with or without changes in our measure of ownership, depending upon whether size distributions alter around defining ownership thresholds. For example, if two shareholders increase their shareholdings from 25 to $30 \%$ they will change conventional measures of concentration but not our measure of ownership. Conversely, if ownership of two shareholders increases from 24 to $26 \%$ there will be a negligible effect on conventional measures but a significant effect on our ownership measure given the significance of a $25 \%$ threshold.

Mutation is related to conventional measures of liquidity but it is not the same. Share turnover, a conventional measure of liquidity, may occur in the absence of changes in controlling shareholders and mutation. Our paper therefore allows conventional measures of liquidity to be disentangled from those that directly affect the market for corporate control. ${ }^{6}$

We examine how changes in dispersion and mutation of ownership have been affected by investor protection and by equity issued for internal investment and acquisitions. We do so by regressing the dispersion and mutation variables on the LLSV measure of anti-directors rights at the beginning of the decade and on equity issued during the decade. We control for the level of dispersion of ownership at the beginning of each decade and, in light of the potential endogeneity of the equity issuance measure, we instrument it using firm and time effects and company age. We undertake these regressions for the first four decades of our sample of 60 companies.

\footnotetext{
${ }^{6}$ We could have taken our analysis further and, instead of defining ownership in relation to control levels of 25,50 or $75 \%$, considered specific actions, for example powers to replace directors, to veto issues of capital etc. Had we done this then ownership would have altered not merely because the size and nature of shareholdings had changed but also because of new legal rulings concerning the rights of shareholders. For example shareholders had little ownership of the new equity issuing process until the 1980 Companies Act conferred pre-emption rights on them

This is a substantive issue. The endogeneity of laws in relation to ownership documented in this paper is not just an empirical observation but also a conceptual one. Ownership is defined by the law and cannot be measured independently of it and the law adapts where ownership is perceived to be inadequate. Most recently this has been witnessed in relation to the determination of executive remuneration and the rights of shareholders over the appointment and replacement of auditors.

We have, however, chosen not to pursue our definition of ownership to this logical conclusion for pragmatic reasons. We wish to demonstrate that even abstracting from legal changes there was a substantial and rapid evolution of ownership from the beginning of the $20^{\text {th }}$ century. Had we chosen to measure ownership in relation to actions not thresholds we would have observed still more change reflecting evolving legal parameters as well as shareholding structures.
} 
We examine the robustness of the results to survivorship by repeating the regressions on the sub-samples of 1900 survivors and non-survivors.

The approach taken in this paper differs from existing ones that examine crosssections of firms at a particular point in time or in some cases at various times, by creating a long-run panel of firms. Our approach has the advantage of allowing the evolution of ownership of firms to be traced and the impact of regulatory and firm-level factors to be subject to standard panel econometric and statistical tests. It also differs from comparisons of cross-sections in so far as it abstracts from entry and exit of firms that occur between the dates of cross-sections. This makes the approach particularly well suited to establishing how and when current ownership patterns emerged.

\section{Capital markets in the U.K. in the $20^{\text {th }}$ century}

In this section, we describe the development of regulation and the size and structure of stock markets in the U.K. during the $20^{\text {th }}$ century.

\subsection{Investor protection}

There was a marked change in financial regulation and investor protection over the $20^{\text {th }}$ century. Although limited liability was introduced into the U.K. in the Companies Act of 1856, it was not until the landmark case of Salomon v. Salomon in 1897 that it was made effective. Such was the enhanced protection that it offered shareholders in the event of financial failure that many companies, including several in our sample, reincorporated after the 1897 ruling and the subsequent Companies Act of 1900.

U.K. common law does not provide minorities with an automatic right of protection. A seminal case in the middle of the $19^{\text {th }}$ century (Foss v. Harbottle (1843)) had exactly the opposite effect of seriously restricting minority shareholder rights for the next hundred years. The judge in the case made two important rulings. First, while the plaintiff in the case was an aggrieved shareholder, he found that the proper plaintiff in an action of an alleged wrong to a company was the company itself, i.e. a majority of the shareholders and not a minority. Secondly, he noted that, where a transaction could be made binding by a majority of the shareholders, no individual shareholder could sustain an action against the company. In another case, Harben v. Phillips (1883), the judge found that there was no common law right on the part of a shareholder to vote by proxy. 
Lord Justice Hoffman (1999) observed that, "the emancipation of minority shareholders is a recent event in company law. For most of the twentieth century minority shareholders were virtually defenceless, kept in cowed submission by a firebreathing and possibly multiple-headed dragon called Foss vs. Harbottle. Only in exceptional cases could they claim protection of the court." He goes on to say: "A statutory remedy was provided for the first time in 1948 but this proved relatively ineffectual. It was not until 1980 that Parliament forged the sword which is now section 459 of the Companies Act 1985 and which enables the unfairly treated minority shareholder to slay the dragon."7 It was legislation that eventually provided minority investors with the protection that common law had for so long denied them.

The lack of minority protection became even more transparent during the 1920s. It has been argued that one of the advantages of common law systems is their ability to adapt to changing economic and social conditions and to promote the emergence of efficient legislation through case law (see Coffee (2001) and Beck, Demirgüç-Kunt and Levine (2003)). However, this does not appear to have promoted minority investor protection in the U.K. In the case of Re Brazilian Rubber Plantations [1911] and City Equitable Fire Insurance Company's [1925] the courts upheld clauses in the companies' articles of association (i.e. corporate charters) that limited directors' liability even in relation to wilful neglect or dereliction of duties. ${ }^{8}$ The response to these clear deficiencies in investor protection was the 1929 Companies Act that rendered such clauses void. The 1929 Act was relatively ineffectual, being passed in the midst of a bull market. Subsequently, the Cohen Committee on Company Law was set up as a result of a growing concern about "dispersion of capital among an increasing number of small shareholders... who are, in many cases, too numerous and too widely dispersed to be able to organise themselves" (Cohen Committee (1945), para. 7). Its conclusions were the basis for the fundamental reforms enshrined in the 1948 Companies Act. The 1948 Act was a defining piece of legislation: it introduced voting by proxy, provisions for shareholders to force an EGM with $10 \%$ of the voting equity capital, and special resolutions to make it easier for shareholders to remove directors.

\footnotetext{
${ }^{7}$ Cited in the foreword to Robin Hollington's Minority Shareholders' Rights, 1999, Sweet and Maxwell, London.

${ }^{8}$ In the City Equitable Fire Insurance case the judge went on to say that a director "is not guilty of wilful neglect or default unless he knows that he is committing and intends to commit a breach of his duty, or is recklessly careless in the sense of not caring whether his act or omission is or is not a breach of his duty."
} 
Table A3 in the Appendix documents important changes in law and financial markets regulation in the UK in the $20^{\text {th }}$ century. ${ }^{9}$ Table 1 uses this information to construct indices of investor protection proposed by LLSV and LLS. Panel A translates minority protection rules into the LLSV score of anti-director rights. Prior to 1948 the score was 1. The Companies Act of 1948 raised the LLSV score to 3 by introducing proxy voting and the right of $10 \%$ of shareholders to call an Extraordinary General Meeting (EGM). The score rose to 5 (out of 6) in the 1980s with the addition of preemption rights in 1980 and protection for oppressed minorities in $1985 .^{10}$

The LLS measures of private and public enforcement paint a similar picture. Panels B, C and D of Table 1 record the average indices of disclosure, liability standards and public enforcement; the separate components are reported in Table A4 of the Appendix. LLS's preferred composite index of private enforcement, the simple arithmetic average of disclosure and liability standards, is zero in 1900, 0.5 in 1929, 0.67 in 1948 and 0.75 in 1967 and thereafter. On this basis, private enforcement was very weak at the beginning of the century and progressively strengthened from 1929. The public enforcement index is zero until the 1986 Financial Services Act.

Turning to disclosure rules described in detail in Table 1 , in the first half of the century, principles of caveat emptor were deeply embedded as captured in this statement by the Greene Committee (1925): “The careless speculator who is willing to accept at their face value statements which are obviously insufficient and unsatisfactory cannot justly expect special protection when that would involve a serious and unwarranted interference with the honest person" (sec. 59). In 1929, a Companies Act required firms to keep both a profit and loss account and balance sheet and both had to be made available to the public at Companies House. In 1939, there was legislation requiring directors to disclose contractual interests in their firms. But accounting disclosure in the first half of the century was guided by such views as those expressed by the Greene Committee in 1925: "We think it most undesirable to lay down hard and fast rules as to the form which a balance sheet should take... The matter of

\footnotetext{
${ }^{9}$ For sources, see for example, Cairncross (1958 and 1953), Code Holland and Werry (1932), Davies (1979), Franks, Mayer and Renneboog (2001), Michie (1999), Morgan and Thomas (1962), Paish (1951), Sargant Florence (1947) and Schwabe and Branson (1913).

${ }^{10}$ Inevitably, LLSV's measure is incomplete as a scorecard of investor rights. For example, in 1967 and thereafter, statutory provisions were introduced for a minority of $25 \%$ of shareholders to block particular merger transactions (Table A3) and waive pre-emption rights. Still more significantly, the City Code on Takeovers and Mergers introduced provisions in 1967 for a mandatory bid when an acquirer has $30 \%$ or more of the target's shares, and an equal price rule in takeovers that effectively prevented discriminatory pricing and limited the formation of large blocks.
} 
accounts is one in which we are satisfied that within reasonable limits companies should be left a free hand" (sec. 69). The 1948 Companies Act introduced disclosure rules for prospectuses and specific penalties for non-disclosure, detailed provisions regarding the content and form of both balance sheets and profit and loss accounts and a requirement that company accounts be prepared on a basis that gives a "true and fair" view of a company's financial position, a litmus test of company accounts that has been applied to the present day.

Table A3 also includes changes to the LSE's listing rules. LSE registered market makers (called jobbers) frequently dealt in shares of companies that had not passed its listing requirements. This occurred when the shares of a company were issued on a provincial exchange, often without a prospectus, and then traded on the LSE under special rules referred to as 'under a supplementary list'. In 1919 the LSE introduced a provision that new share issues had to be accompanied by either a prospectus or an advertisement. However, this provision was not effective because the information required in the advertisements was limited and securities could be traded on the supplementary list of the LSE without fulfilling its disclosure requirements (see Michie (1999) pp 265-6). From 1947, the distinction between the official and supplementary lists was abolished and all companies were required to satisfy the LSE's listing rules, including an obligation to produce a ten years profit record and to have the support of two registered jobbers (i.e. market makers). The listing rules had an important effect on the equity issuance process and reinforce the view that there was a discrete change in investor protection at the end of the 1940's.

In many respects, 1948 was a defining date for minority investor protection. The anti-directors index rose from 1 to 3 , the liability standards index rose from 0.33 to 0.67 and the LSE strengthened listing rules. In choosing 1948 over other years, 1929 or the 1980s when there were other changes in the LLSV and LLS scores, we place considerable importance on the significant tightening of the LSE's listing rules in 1947. Moreover, while many disclosure requirements relating to $\mathrm{P} \& \mathrm{~L}$ accounts and balance sheets had been introduced earlier in the century, it was only with the detailed stipulation of their content and the requirement that they provided a "true and fair" view that they became a reliable source of information. For example, Roberts (1993) notes that until 1948 there was insufficient information on which predators could launch acquisitions without the co-operation of managers of the target firm. It is therefore no coincidence that with the passing of the 1948 Companies Act, Charles Clore was able to 
bypass the board of Sears Ltd and initiate the first hostile tender offer in the U.K. in 1953. ${ }^{11}$

It is not just relative to the second half of the $20^{\text {th }}$ century that investor protection in the first half was weak. It was also weak relative to what we now regard as weak investor protection systems elsewhere in the world. The U.K.'s score of one on the LLSV measure for anti-director rights in the first half of the century is on a par with Germany's in the 1990s as reported by LLSV. ${ }^{12}$ Furthermore, there are several features of investor protection that have been present in Germany throughout the twentieth century that were not and never have been present in the U.K. There has been an extensive system of non-executive oversight of corporate activities in Germany since the company law of 1884 required a separation of supervisory, i.e. non-executive, from management boards. A solution to the collective action problem that minority investors face in voting shares existed for much of the $20^{\text {th }}$ century in Germany through proxy voting by banks ${ }^{13}$, and minorities frequently enforce their rights through the courts in Germany (see, for example, Franks and Mayer (1998)), in a way in which they rarely do even today in the U.K.

Common law was not therefore a sufficient condition for strong investor protection in the U.K. by today's standards. The comparison of the U.K. in the first half of the century with Germany today raises the question of how two countries with similarly weak investor protection could produce such different capital markets. It casts doubt on whether formal investor protection can provide an adequate explanation.

\subsection{Size and structure of U.K. stock markets}

Rajan and Zingales (2003) examine the importance of stock markets around the world. They report the ratio of aggregate market value of equity of domestic companies to GDP for 26 countries between 1913 and 1999, at approximately ten-year intervals. Using their criterion, the U.K. has a stock market that ranks in first or second place in six of the nine decades and in the top five for the remaining three decades. The ratio of market capitalization to GDP in the UK was 2.42 in 1900 and 2.25 in 1999.

\footnotetext{
${ }^{11}$ Roberts (1992) states that "Clore launched his attack on being informed by a partner in the estates agent Healey \& Baker that Sears' balance sheet under-estimated the real estate value of the firm's 900 high street stores by $£ 10$ million" (page 186).

${ }^{12}$ The score of 1 for Germany reflects the provision of a $5 \%$ threshold for calling an EGM introduced by statute in 1965 (Aktiengesetz, Section 122).

${ }^{13}$ Nibler (1996) reports that in 1991 three German banks controlled almost $30 \%$ of the voting rights of 38 of the largest publicly quoted companies through proxy votes.
} 
There is other evidence consistent with Rajan and Zingales' (2003) picture of a flourishing U.K. stock market during the century. Michie (1999) records an increase in the number of listed companies from 200 in 1853 to "many thousands" in 1914. Hart and Prais (1956) provide more precise estimates on industrial companies: they record 60 listed companies in 1885, 571 in 1907 and 1,712 in 1939. By number of listed companies, the most significant decline in the size of the London Stock Exchange has occurred in the last forty years with 4,409 listed companies in 1963 falling to $1,904^{14}$ in 2000.

One striking feature of stock exchanges in the U.K. in the first half of the twentieth century was the importance of regional exchanges. Today there are just two exchanges in the U.K. but in the first half of the century there were 18 provincial stock exchanges, which collectively were as large as the London Stock Exchange. ${ }^{15}$ According to Phillips' Investors Manual of 1885, 'the provincial exchanges are of almost greater importance in relation to home securities than London'. Thomas (1973) states that: "the number of commercial and industrial companies quoted in the Manchester stock exchange list increased from 70 in 1885 to nearly 220 in 1906. Most of these were small companies with capitals ranging from $£ 50,000$ to $£ 200,000$ ” and "by the mid 1880s Sheffield, along with Oldham, was one of the two most important centres of joint stock in the country, with 44 companies, with a paid up capital of $£ 12$ million.' (pages 133 and 124). Table A2 shows that at the end of 1899 only $46.6 \%$ of English quoted companies were listed on just the London Stock Exchange.

Provincial stock markets played an important role in promoting new issues. Writing in 1921 on new shares issues, Lavington notes that "local knowledge on the part of the investor both of the business reputation of the vendor and the prospects of his undertaking would do a good deal to eliminate dishonest promotion and ensure that securities were sold at fair prices fairly near their investment values." Concentrating ownership among local investors was recognized as a method of reducing information problems as well as fraud. Lavington (1921) cites the views of one broker: "the securities are rarely sold by means of a prospectus and are not underwritten, they are placed by private negotiation among local people who understand the [cotton] trade" (p. 280).

\footnotetext{
${ }^{14}$ Excluding AIM where there are about another 800 small listed companies.

15 The four largest in order of size were Manchester, Sheffield, Newcastle and Cardiff. Interestingly, the reopening of the Birmingham Stock Exchange has recently been proposed by a government agency as "a means of stimulating local economic growth" (Financial Times, 26 August 2003, p. 4)
} 
The Birmingham exchange was important for cycle and rubber tube stocks, Sheffield for iron, coal and steel and Bradford for wool. Securities were traded in the city in which most investors resided. For example, shareholders in Manchester were anxious that the shares of the Patent Nut and Bolt Co. of Birmingham should be listed in Manchester where most of the shareholders lived (see Thomas (1973), p. 118). The reason was that proximity between brokers and directors was thought to create betterinformed markets.

Based on these observations, we formulate an alternative to the law and finance thesis namely that it was informal relations of trust between investors and firms rather than formal systems of regulation that allowed equity markets to flourish and ownership to become dispersed in the U.K. in the first half of the $20^{\text {th }}$ century.

\section{Equity Financing}

In this section we record growth in equity capital of our samples of firms and the use to which the finance is put.

Companies in our samples issued three classes of securities: ordinary shares, preference shares and debentures. Ordinary shares accounted for just less than $60 \%$ of issued securities in both 1920 and 1930 by face value. There was only one class of ordinary shares and, unlike Continental European companies, a complete absence of dual class shares with differential voting rights. ${ }^{16}$ The absence of dual class shares was by choice rather than by law - the U.K. has never had regulation prohibiting dual class shares. However, widespread use was made of preference shares, around $30 \%$ of issued securities in our sample. In fact, several companies had more than one type of preference share. These shares in general do not carry voting rights and in return receive a preferential dividend. The remaining $10 \%$ of securities were debentures.

Table 2 describes the growth of issued ordinary equity of the 1900 sample in Panel A and of the 1960 sample in Panel B. The mean annual growth of issued equity was $10.6 \%$ over a hundred years for the 1900 sample and $22.1 \%$ for the 1960 sample over the remaining 40 years of the century. The mean growth rate in the first forty years of the 1900 sample was $10.8 \%$. In both samples, much of the growth is concentrated in the first decade.

\footnotetext{
${ }^{16}$ Florence (1953) refers to the existence of shares with differential voting rights in his sample of companies. Evidence on capital structure in our sample strongly suggests that these are primarily associated with preference shares. However, dual class shares did emerge in the U.K. after 1948 (see Franks, Mayer and Rossi (2005)) in response to the emergence of a market for corporate control.
} 
The last four columns of Panel A record the percentage of equity issued for acquisition and internal investment. Acquisitions are broken down into those that used cash and equity as the medium of exchange. In a cash acquisition, equity is issued for cash in advance of the transaction with the stated intention of acquiring another firm while, in an equity offer, the acquiring company's shares are exchanged for those of the target at the time of the transaction. ${ }^{17}$ Equity issued for internal investment is disaggregated into issues made to existing and new shareholders.

Panel A shows that in the first decade of the 1900 sample, equity was issued virtually exclusively for acquisitions. There was little or no equity issued for internal investment. During the century as a whole, cash and equity acquisitions together accounted for $71 \%$ of equity issued by the 1900 sample and $64 \%$ by the 1960 sample.

A majority of the equity issued for acquisitions was associated with equity exchanges rather than cash purchases. This is particularly pronounced in the 1900 sample. A higher percentage of equity was used to finance internal investment in the 1960 than the 1900 sample, particularly in the first decade after incorporation.

Panel C reports the statistical significance of the differences between Panels A and $\mathrm{B}$ in the first four decades after incorporation. The first column compares 1960-70 with 1900-10, the second 1970-80 with 1910-20 etc. The rows report t-statistics for differences in total growth, growth attributable to share acquisitions, cash acquisitions, and financing of internal investment. In panels D and E, the 1960 sample is compared with the 1900 survivors and non-survivors.

Row 1 of Panel $\mathrm{C}$ shows that growth rates of issued equity are significantly higher at the 5\% level in the 1960 sample than in the complete 1900 sample. This is particularly pronounced in the first decade after incorporation and is entirely associated with the 1900 non-survivors (Panel E). There is no significant difference in the comparison of the 1960 sample with the 1900 survivors (Panel D). Rows 2 to 4 show that the difference in growth is associated with equity issued for internal investment rather than for acquisitions, particularly in the first and fourth decades after incorporation. $^{18}$

In summary, the overwhelming use to which equity issuance was put in the first and second half of the century was the financing of acquisitions. Most was used in the direct exchange of shares rather than in cash purchases, particularly in the first half of

\footnotetext{
${ }^{17}$ Cash acquisitions financed from debt and cash reserves are not shown.

${ }^{18}$ These results continue to hold when the three companies in the 1900 sample that died within 40 years of incorporation are excluded.
} 
the century. Equity issuance for internal investment was slightly greater in the second than the first half of the century but modest in both. Rates of growth of equity capital are similar in the 1900 and the 1960 sample and differences are restricted to comparisons of the 1960 sample with the sample of non-surviving 1900 firms.

The significance of acquisitions in our samples is consistent with Hannah's (1976) observations of a large amount of takeover activity in the U.K. during the $20^{\text {th }}$ century, particularly in three merger waves during the first half of the century, around 1900, 1920 and 1930, and with Meeks and Whittington (1975) statements on the importance of equity in the takeover process: "in 1964-9, the giant (or mature) corporations ...typically financed almost $70 \%$ of their growth by new issues; and even the rest of the sector financed more than half (56\%) of their growth through the capital market in this period...more than half of these external funds were raised in the course of share for share exchanges on the acquisition of new subsidiaries" (p. 832).

One example of this is GKN, a company that was involved in a particularly large amount of acquisition activity in the 1920s. First, the company acquired John Lysaght Limited of Bristol (quoted in Bristol and London) in one of the largest tender offers of the decade. GKN then undertook two other major tender offers in November 1923, acquiring D Davis and Sons and Consolidated Cambrian of Cardiff. In both cases $96 \%$ of the outstanding ordinary shares were exchanged. As a consequence of these acquisitions, there was a huge increase in the number of shareholders: GKN had about 1,000 shareholders before 1920 and more than 20,000 in 1924 .

The results provide little support for the importance of investor protection to external financing. There was a great deal of equity issuance in the first as well as the second half of the century in the absence of investor protection. Acquisitions were a primary use of new equity throughout. There is some evidence of more equity issuance to fund internal investment in the second half of the century but only when the 1960 sample of firms is compared with a sample of non-surviving firms in the first half. Furthermore extending the law and finance thesis to takeovers, improved investor protection should have encouraged target shareholders to accept equity as the medium of exchange in acquisitions in the second half of the century (see Rossi and Volpin 2004 for a discussion of this). That is not what is observed here; on the contrary, exchanges of shares accounted for a higher proportion of acquisitions in the first than in the second half of the century. 


\section{Dynamics of ownership through the century}

In this section we examine the evolution of ownership of our samples of firms over the $20^{\text {th }}$ century. We begin in Section 5.1 by looking at concentration and the nature of share ownership. In Section 5.2 we examine the rate at which share ownership is dispersed and the rate of mutation of the controlling group of shareholders. In Section 5.3 we report the results of panel regressions on the determinants of dispersion and mutation of ownership.

\subsection{Concentration and nature of share ownership}

We report two sets of statistics on the concentration and nature of share ownership. The first records the minimum number of shareholders required to reach critical ownership thresholds and the second the (more conventional) total shareholdings owned by the largest shareholders.

Table 3 documents the smallest ownership coalition (including both insiders and outsiders) that passes a combined threshold of $25 \%$ at different stages during the century. Table A5 reproduces the same statistics for a $50 \%$ threshold. It records very similar results to Table 3. The remainder of the discussion will focus on the $25 \%$ threshold, since other measures cannot be reproduced for the higher threshold. ${ }^{19}$

Panel A of Table 3 refers to the complete 1900 sample and Panel B to the 1960 sample. The variable "all shareholders" is the size of the smallest coalition of directors and outsiders combined that is required to pass a $25 \%$ cash-flow threshold. The mean minimum size of the coalition rises from just above 2 in 1900 to about 7 in 1910 to 10 in 1930, peaking at 58 in 1980. Median dispersion is lower reflecting the skewed nature of the distribution, a small number of firms having high levels of dispersion.

The remaining columns refer to the minimum average size of coalitions of directors and outsiders, respectively, which individually cross the $25 \%$ threshold. To illustrate, in 1900 directors could on their own cross the $25 \%$ threshold in 39 of the 40 companies and on average it took 1.77 directors to do this. In the same year, in only 10 companies could outsiders on their own cross the $25 \%$ threshold and it took on average 15.40 shareholders; in the remaining 30 no such coalition could be formed from

\footnotetext{
19 Our measures of dispersion refer to ownership at the first tier only. Since large blocks of shares are frequently held by institutions on behalf of other investors, ultimate shareholdings will in general be more dispersed. However, measurement of dispersion at the first tier may be justified by the fact that it captures concentration of control rather than cash flow rights better than that at higher tiers.
} 
outsiders alone. By 1920 this position had been reversed. There were then more companies in which outsiders could cross the $25 \%$ threshold than insiders, 27 as against 26. By the end of the century there were just 3 companies in which directors could on their own cross the threshold compared with 19 for outsiders out of the 20 survivors.

We therefore observe steadily increasing dispersion of ownership through the century with outsiders progressively replacing insiders as the dominant shareholders. In 1900 it took 15 outsiders on average whereas by 1980 it took over 60. In contrast, while there were progressively fewer companies in which directors could pass the threshold, the number of directors it took to do so remained fairly constant at between 1 and 3. The sample therefore bifurcates between those firms where insider ownership is being diluted and outsiders are progressively replacing them and a declining minority in which a small number of insiders continue to dominate.

Panel A also reveals another feature and that is a reversal of dispersion in the last two decades of the century. The mean number of shareholders in the 1900 sample required to pass the $25 \%$ threshold declined from 57.9 to 48.4 between 1980 and 2000 and the median from 8 to 3 . The cause of this was the rise of institutional shareholdings that continued the transfer of ownership from insiders to outsiders and raised the concentration of outside shareholders. For example, the average size of share blocks held by financial institutions in the 1900 sample rose from $6.5 \%$ in 1980 to $12.8 \%$ in 2000.

In Panel B, the 1960 sample shows a similar pattern to the 1900 sample: the number of companies where directors can form a coalition steadily falls over the 40 years, while the number of companies with outsider coalitions rises sharply. However, the size of the coalition is generally lower for the 1960 than the 1900 sample, implying greater concentration in the 1960 sample.

In 1940 a coalition of about 15 shareholders is required to pass the $25 \%$ threshold compared with only about 4 for the 1960 sample in 2000. For directors in 1940 , there are 13 cases where a coalition of $25 \%$ or more could be formed compared with only 5 cases in 2000. But the main difference is in the number of outside shareholders required to reach the $25 \%$ threshold. In 1940 on average 22 shareholders were required whereas in 2000 only just over 5. While there is therefore substitution of outside for director ownership in the 1960 as in the 1900 sample, concentration of outside and overall ownership remains higher in the 1960 sample. 
In Panels C, D and E we report t-statistics comparing the size of the coalition in the 1960 sample with the full 1900 sample, the survivors in the 1900 sample only and the non-survivors, respectively. The only year in which there are significant differences is 2000 versus 1940 in the survivors' sample in Panel D. The size of the coalition is then significantly smaller in the 1960 sample at the 5\% level.

In Table A5, we repeat the analysis for a $50 \%$ instead of a $25 \%$ ownership threshold. The overall picture is very similar: a smaller coalition of all and, in particular, outside shareholders is required to cross this higher threshold in the 1960 sample than in the 1900 sample. For example, on average only 15 shareholders are needed to form a coalition in 2000 for the 1960 sample compared with about 37 in 1940 for the 1900 sample.

The main result to emerge thus far is that dispersion of ownership is at least as great in the 1900 as in the 1960 sample and possible slightly higher in some years. The threshold measures provide a particularly informative description of the control that shareholders can exert. However, for completeness, in Table 4 we examine more conventional measures of ownership concentration used in the literature, namely the size of the directors' holdings, the size of the largest three (C3) and five (C5) shareholdings, with the $\mathrm{C} 3$ measure broken down between insiders and outsiders, and a Herfindahl index.

As observed above in relation to Table 3, concentration amongst directors is lower in the 1960 than in the 1900 sample (significant at the 5\% level overall). Further, C3 is higher in 1940 for the 1900 sample than in 2000 for the 1960 sample, although the difference is statistically insignificant; this largely reflects different patterns of insider ownership (C3i). In contrast, C3o is significantly higher (at the $1 \%$ level) over the first 40 years in the 1960 than in the 1900 sample. Panels D and E show that the lower level of concentration of outsiders in the 1960 sample holds in comparison with both the 1900 survivor and non-survivor samples. The higher concentration of outsiders in the second half of the century reflects the rise of institutional investors.

Comparing changes over time in Panels A and B of Tables 3 and 4 illustrates the advantage, referred to above in the methodology section, of the critical threshold measures over conventional concentration indices. The decline in the concentration indices in Table 4 of the 1960 relative to the 1900 sample (Panel B relative to Panel A) is faster than the increase in the minimum number of shareholders in Table 3 of the 
1960 relative to the 1900 sample. This is associated with a switch from inside to outside ownership, which became more rapid as the century progressed. As institutional ownership increased, outside ownership became more concentrated. There were therefore differences between the two samples in the change in concentration indices without corresponding differences in the change in the critical number of controlling shareholders.

Table 5 reports the factors contributing to changes in directors' shareholdings. To illustrate our calculations, consider the decade between 1900 and 1910. Table 4 shows that directors' ownership declined by $39.15 \%$ from $92.76 \%$ in 1900 to $53.61 \%$ in 1910 (see Panel A of Table 4). Table 5 records that $39.06 \%$ of this decrease, referred to as 'impact', is associated with acquisitions. The 25 stock acquisitions between 1900 and 1910 therefore account for a decrease in directors' ownership of $15.34 \%$ (i.e. 39.15 x 39.06\%). Similar computations for the 1960 sample show that the 27 acquisitions during the decade 1960-70 account for a decrease of 28.92\% in directors' ownership. ${ }^{20}$

There are a number of striking features about Table 5. First, the decline of insider ownership is rapid in both the 1900 and the 1960 samples. Within ten years directors' shareholdings in both samples decline very significantly by $39.15 \%$ and $53.04 \%$ respectively. As described above, the rapidity of the decline is higher in the 1960 than in the 1900 sample. Second, the main reason for the decline is not sales of shares by directors in the secondary market, at least in the first half of the century for the 1900 sample. Instead, over the period 1900 to 1950, issues of shares associated with acquisitions, rights issues and placings account for $56.43 \%$ of the decline. ${ }^{21}$ Third, of this decline through issues of shares, more than half $(35.06 \%$ of the $56.43 \%)$ is associated with acquisitions. Issue of shares in takeovers is the single most important cause of the decline in director holdings. This raises the possibility, which we do not pursue here, that differences in takeover activity across countries explain at least some of the differences in dispersion of ownership.

\footnotetext{
${ }^{20}$ Note that the various factors do not sum to 100 , the residual being primarily due to sales of shares by directors.

${ }^{21} 56.43 \%$ is the sum of the reductions in director shareholdings attributable to each of the three types over the total reduction in directors' shareholdings. For example, a reduction in shareholdings due to acquisitions in $1900-1910$ is $39.15 \times 39.06 \%$. The sum of these reductions over all three classes over all five decades is the numerator of the fraction equalling $56.43 \%$. The denominator is the total reduction in directors' shareholdings over the 5 decades.
} 


\subsection{Dispersion and mutation}

In this section we estimate measures of rates of dispersion and mutation of ownership of the two samples of firms. An analysis of rates of change has the advantage over levels of being less influenced by initial conditions. Panel A of Table 6 reports rates of dispersion of ownership for all shareholders in the 1900 sample, and for inside and outside shareholders separately. The rate of dispersion for all shareholders in the first decade is $5.93 \%$ per year. This tells us that the number of shareholders required to form a coalition of at least a $25 \%$ shareholding increases at a rate of $5.93 \%$ per year over the decade. For example, if the number of shareholders required to meet the $25 \%$ threshold had been 5 in 1900 it would have been 8.9 in $1910 .^{22}$

For the 1900 sample, rates of dispersion in the first half of the century are generally higher than in the second half. They are close to zero from 1960 onwards, and actually negative in the eighties, suggesting an increase in concentration arising from the formation of blocks, as reported in previous tables. Dispersion rates for directors are positive for all decades except two and particularly high for the decades 1900 to 1940 and 1970 to 1990 .

The rates of dispersion for the 1960 sample are shown in Panel B. In Panel C, we compare the dispersion rates of the two samples for the first four decades after incorporation. The evidence suggests that dispersion rates for the two samples are not very different. Focusing initially on the comparison for 'all shareholders', we find that in two of the four decades dispersion rates are higher for the 1960 sample. Only in the second decade, is the difference statistically significant (at the 10\% level) and then it is the 1900 sample that has the higher rate of dispersion. Although differences can be economically large in individual decades, averaged over the first four decades they are not, $3.65 \%$ for the 1900 sample and $3.63 \%$ for the 1960 sample.

For the first four decades after incorporation dispersion rates for 'outsiders' are greater in the 1960 sample, and the difference is statistically significant. This is mainly attributable to the first decade, 1960-1970, and reflects the relatively high number of IPOs in the 1960 sample (10 out of 20 companies). [The fact that rates of dispersion do not differ for 'all shareholders' in the first decade for the two samples suggests that

\footnotetext{
22 Note that it is not possible to relate these figures exactly back to those in Table 3 , since numbers constructed from averages of growth rates are not the same as those derived from averaging across the firms themselves.
} 
sales by directors in IPOs in the 1960 sample were purchased by large outside shareholders, i.e. there were high rates of mutation of ownership. $\left.{ }^{23}\right]$

Panels D and E report t-tests comparing the 1960 sample with the 1900 survivors and non-survivors respectively. The results are very similar to Panel $\mathrm{C}$ and suggest that survivorship is not an issue for tests of dispersion of ownership. ${ }^{24}$ One of the interesting implications is that, despite the fact that the growth in equity of survivors is greater than that of non-survivors rates of dispersion of ownership were similar. The reason for this is that most of the difference in growth is due to internal investment and, as we will report in the next section, it is equity issuance for acquisition rather than internal investment that accounts for dispersion of ownership.

In Table 7 we describe mutation of ownership and control, a measure of the stability of the membership of the smallest coalition necessary to pass the $25 \%$ threshold. High rates of mutation are associated with rapid changes in the control of firms. Panel A reports much higher rates of mutation in the 1900 sample in the second than in the first half of the century. The average rate of mutation or turnover of the coalition is $26.52 \%$ per annum in the 1900 sample. The corresponding figure for the 1960 sample is $40.10 \%$ per annum. Another interpretation of these mutation measures is that the average length of membership of the ruling coalition is about 4 years in the 1900 sample compared with only 2.5 years in the 1960 sample.

Panel $\mathrm{C}$ reports results from t-tests comparing rates of mutation for the first four decades for both samples. The levels of significance reported in this table stand in marked contrast to those on dispersion. The 1960 sample has strikingly higher rates of mutation than the 1900 sample, and the differences are statistically significant at the $1 \%$ level for all classes of shareholders. The higher rates of mutation are particularly pronounced in the third and fourth decades. Similarly, rates of mutation of the 1900 sample are much higher post-1940 than pre-1940 and particularly so after 1980 . The same highly significant results are observed when comparing the 1960 sample with both the 1900 survivors and non-survivors in Panels D and E respectively. ${ }^{25}$ As in the case of dispersion, comparisons of mutation rates are not particularly sensitive to

\footnotetext{
${ }^{23}$ Although the post IPO outside blocks must have been smaller than the pre IPO blocks as indicated by the increase in dispersion of outside shareholdings.

${ }^{24}$ In Table A6, we report results using a threshold of 50\%. The picture is very similar with high rates of dispersion at the beginning of the century, and no significant difference of overall dispersion rates between the first four decades of the 1900 and 1960 sample.

${ }^{25}$ The last row of Panels C, D and E of Table 7 records differences in mutation of board representation as well as director ownership. It shows much higher levels of board turnover in the 1960 than the 1900 sample.
} 
survivorship. Intensification of regulation during the century therefore appears to have been associated with steadily higher rates of mutation rather than dispersion of ownership.

In summary, we observe that rates of dispersion of ownership were similar in the two halves of the century but rates of mutation of the coalition of shareholders were appreciably higher in the second half. The implication is that there were more liquid markets in and for corporate control in the second half of the century. Greater liquidity in share stakes potentially made it easier for active investors to gain control of under performing firms exercising control either through the share stake itself or through a subsequent full-scale tender offer.

\subsection{Regression results}

In this section we report regression analyses of rates of dispersion and mutation to establish whether the results carry over to a multivariate setting. Thus far we have been unable to control for the numerous other factors that might influence dispersion and mutation rates. In this section we control for these by including time and firm effects and we provide a direct test of how dispersion and mutation relate to equity issuance and the LLSV and LLS indices.

The dependent variables in Tables 8 and 9 are rates of dispersion and mutation for "all shareholders" as described in Tables 6 and 7 respectively. The main independent variables are four measures of investor protection and enforcement: antidirector rights, disclosure standards, liability standards, and public enforcement, as described in Table 1. Additional explanatory variables include equity issued for internal investment, equity issued for acquisitions, dispersion of equity at the beginning of the decade, size, and decade and industry dummies. The results show that none of the proxies for investor protection and enforcement positively affect dispersion; if anything the relationship is negative. Investor protection does not therefore explain dispersion of ownership in the U.K.

The results show a significant negative relation of rates of dispersion during a decade with initial levels of dispersion measured at the beginning of the decade. Thus the higher the initial level, the lower the subsequent rate of dispersion. More interestingly, the results show a positive relation between rates of dispersion and equity growth rates resulting from stock acquisitions but not from equity issued to fund internal investment. Although not shown in the table, this result continues to hold when 
the equity growth rate variables are instrumented. Also, when we split the samples into the 40 surviving and the 20 non-surviving companies, we find no significant difference in the estimated coefficients on the two sub-samples.

In contrast, there is a consistently significant relation between rates of mutation in Table 9 with LLSV's and LLS's proxies of investor protection and enforcement. Anti-director rights, disclosure standards, liability standards, and public enforcement are all associated with significantly higher rates of mutation, confirming an earlier result that regulation made stock markets more liquid and facilitated the transfer of inside blocks to outside shareholders. As might be expected, mutation during the decade is directly related to dispersion of ownership at the beginning of the decade and there is some evidence that equity issued for internal investment is associated with higher mutation. The latter result is not, however, robust to instrumenting the growth rate variables.

Dispersion of ownership is therefore associated with growth of issued equity, particularly in acquisitions, not with changes in regulation. Regulation, on the other hand, is associated with greater liquidity of markets in controlling shareholding blocks. In the absence of investor protection, controlling shareholdings were comparatively stable and relations based on trust allowed firms to issue equity that dispersed ownership rapidly. The strengthening of regulation promoted markets in and for corporate control that undermined relations based on trust, and made it easier for a market in corporate control to develop.

\section{$6 \quad$ Trust}

If investor protection does not explain the evolution and dispersion of ownership in the UK, what does? In this section we suggest that informal relations of trust rather than formal systems of regulation promoted the development of capital markets and dispersion of ownership in the UK.

In economics, trust is associated with reputation and commitment between players engaged in repeated games with each other (e.g. Kreps and Wilson (1982), Milgrom and Roberts (1982), Gomes (2000)) and with the emergence of particular institutional arrangements (e.g. North and Weingast (1989), Greif (1993) and Mauro and Yafeh (2003)). In law, a distinction is drawn between contracts where there are reciprocal arrangements between parties and trust law where there are unidirectional agreements between beneficiaries and trustees. Where there is no reciprocity in trusts 
on the part of the beneficiary there is a greater fiduciary responsibility on the other party, namely the trustee. Trust arrangements carried over to company law because of the analogous relationship between directors and their dispersed shareholders with that of trustees and their beneficiaries. ${ }^{26}$

Our concept of trust in a corporation draws on both economics and law and refers to actions by the director of a firm that are dictated neither by contract nor by regulation. By trust we mean conformity with accepted norms of behaviour in the absence of explicit incentives or penalties to do so. It can derive from repeated interactions as described in the economics literature, from moral and ethical codes, or from the social conventions and networks discussed in the extensive sociological literature on the subject (see for example Banfield (1958), Coleman (1990) and Spagnolo (1999)).

We provide evidence of trust based upon shareholder proximity and an equal price rule in mergers. First, following Lavington (1921), in Section 6.1 we argue that the local nature of stock exchanges played an important role in the development of trust between directors and investors. We show that ordinary shareholders lived close to the company's city of incorporation and its board of directors and we argue that relations of trust flourished as a consequence of this close proximity of investors to firms. ${ }^{27}$

Second, in Section 6.2 we examine the way in which firms made offers to shareholders in takeovers and mergers and we provide evidence that the same price was offered to all shareholders even in the absence of a specific regulatory or contractual requirement. We argue that relations of trust created the conditions in which

\footnotetext{
${ }^{26}$ Trust and fiduciary duty is a firmly established concept in English law. The fiduciary responsibilities of directors derive under English law from principles of "equity" and not common law. LS Sealy (1967) describes in his classic article "the Director as Trustee", that at first directors and trustees were essentially regarded as one and the same and any difference was semantic: "the directors had accepted an appointment or "trust"; therefore they were "trustees" and accountable for "breaches of trust". However, there are also important distinctions: trustees act by unanimity, directors by majority. Directors can own shares in their own companies, they may rely on the opinions of others, they can plead that their actions were governed by business judgement and they can devote only a modest amount of time to their functions. Having established that a director was in a position of trust in relation to the company, the law then stood back from imposing the strict obligations of a trustee on directors and allowed directors considerable discretion in the exercise of their duties. The Cohen committee (1945) recognized the importance of this distinction when they commented: "the use of the term 'trustee' may well lead the debenture-holder to the belief that he is getting more effective protection than is the fact."

${ }^{27}$ There is a growing literature on the relevance of distance to banking (Degryse and Ongena (2005) and Petersen and Rajan (1994) and (2002)), securities markets participation (Grinblatt and Keloharju (2001), Hong, Kubik and Stein (2004)), and financial development (Guiso, Sapienza and Zingales (2004), (2005)).
} 
interactions between firms and investors were repeated and where directors therefore had incentives to sustain their reputations amongst local communities.

This thesis suggests that target directors played an important role in validating the terms of acquisitions and that target shareholders placed considerable reliance on their recommendations. Section 6.2 reports qualitative evidence on this and in Section 6.3 we undertake a more formal test by examining the relation between retention of the chairman of the board, the distance between acquiring and target firms, and the medium of exchange. Were trust harder to sustain over long distances then we would expect to observe a higher level of retention of the chairman of the board of the target in mergers between distant firms compared with those in close proximity. We would also expect to observe a greater reliance on the advice of the target directors where the equity rather than the cash of the acquiring firm is on offer.

\subsection{Distance}

We collected comprehensive data on the shareholder records of twenty-six companies in 1910. We recorded the names and addresses of shareholders, and calculated the distance between the shareholder's address and the city of incorporation. Using the data on distance, we compute measures of proximity, including simple and weighted average distances, the median distance, and the proportion living within six miles of the city of incorporation. We collected data on all directors' shareholdings and those of the largest ten outside shareholdings. In addition, we randomly sample every tenth shareholder, with a minimum of 200 shareholders. We also collected the same data for holders of preference shares.

In Panel A of Table 10 we report results for the sample of twenty-six companies in 1910, where the average number of shareholders is 320 . The mean distance between ordinary shareholders' addresses and firms' cities of incorporation is 52.2 miles and the median is 15.4 miles. The proportion living within six miles of the city of incorporation is $56 \%{ }^{28}$ Geographical concentration was therefore remarkably high even where ownership was dispersed. For one company, GKN, we found that geographic dispersion sharply increased over the period 1910 to 1950. Average distance

\footnotetext{
${ }^{28}$ There are two reasons why this last figure is if anything an understatement of geographical concentration. First, where the city of incorporation is not in the same city as the local stock exchange, shareholders often cluster around the latter. Second, in the case of companies incorporated in London distances greater than six miles may be recorded for investors living in the Greater London conurbation. Thus, the metric of less than six miles may be inappropriate where the city of incorporation is a large metropolis, like London.
} 
of shareholders to the head office in Birmingham rose from 69.5 to more than 150 miles.

Panel A of Table 10 also records that the distance between shareholders' addresses and cities of incorporation is greater for preference than for ordinary shareholders and the difference is statistically significant. The greater distance of holders of preference shares may reflect the higher priority of their claims and the less discretion of management over the size of their dividends.

\subsection{Discriminatory pricing in takeovers.}

Even today, discriminatory pricing in takeovers is commonplace. Franks and Mayer (2001) document clear evidence in Germany of discriminatory pricing between large block holders and small investors in takeovers during the 1990s. ${ }^{29}$ But surprisingly this was not a feature of takeovers in the U.K. in the first half of the $20^{\text {th }}$ century.

During the first half of the century takeovers were negotiated between the boards of directors of the relevant companies. Hannah (1974b) describes the takeover process as follows: "An approach through the directors, followed by controlled stock transfers on the recommendations of the directors (rather than contested takeover raids) remained the norm in these years" (p. 68). For example, in the acquisition of John Lysaght Limited by GKN, the directors agreed the terms of the deal (i.e. an exchange ratio) and then wrote to their shareholders stating that "the offer has been unanimously accepted by the Directors of your company for the whole of their individual shares, and

they have no hesitation in recommending its acceptance to the shareholders." 30 The same terms would be offered to outside shareholders as to the directors.

Hannah (1974b) describes how in the first half of the century "the loyalty of shareholders to directors was strong, and the directors of other companies had a natural aversion to challenging it. Even if a direct bid were to be made, the directors of the victim firm remained in a strong position relative to their own shareholders. In practice the shareholders would recognize the superiority of the directors' information and tend to take their advice on the true value of the company in relation to the bid price" (p. 7071). "Directors felt a responsibility to recommend offers to their shareholders when the

\footnotetext{
${ }^{29}$ See also Dyck and Zingales (2004) for international evidence of private benefits of control arising from discriminatory pricing in block purchases.

${ }^{30}$ Quoted in Financial Times, Monday 19 January 1920.
} 
bid price was pitched reasonably" (p. 68-69). ${ }^{31}$ This may have reflected a concern on the part of directors to preserve their reputation amongst local investors so as to sustain the value of their equity and thereby their ability to raise equity at low cost in the future. ${ }^{32}$

Table A7 describes some characteristics of the takeover process in the U.K. in the first half of the century. Panel A lists all acquisitions undertaken by our sample of firms where equity was used as the medium of exchange. Twelve of the target companies are private and not listed on any stock exchange, although they frequently had a large number of shareholders. ${ }^{33}$ The other six targets are listed companies and in all cases there are no pre-bid toeholds and offers were made to all outside shareholders at the same price as that paid to directors for their holdings. The outcome was that between $96 \%$ and $100 \%$ of shares were acquired. Panel B lists the 33 large tender offers in Hannah's (1976) sample. It records that in 27 cases the medium of exchange was at least part equity and that in 31 cases the outcome of the bids involved the acquisition of between $92 \%$ and $100 \%$ of outstanding shares.

We undertook an extensive search of the Financial Times (FT) to find mention of the terms on which acquisitions were made in the first half of the 20th century. We found data on 27 mergers. ${ }^{34}$ Panel $\mathrm{C}$ of Table A4 quotes the precise public statements by the directors of the target company or the reference to the directors' recommendation reported in the FT. It records that in most cases there is a specific reference to equal terms for directors and outside shareholders, and in other cases equal terms can be inferred from the description. In contrast to this equal price rule for the U.K., there were discriminatory block purchases in the latter part of the century in other countries;

\footnotetext{
${ }^{31}$ It was part of a wider role for trust in British financial affairs. In response to a suggestion of tightening regulation of the issuance of prospectuses, the Economist asked whether it "might not be wise to devote increased attention to the possibility of reforming public taste rather than the statute law. Many things which are perfectly legal in this country are not the acts of a gentleman" and are "just not cricket" (July 10, 1937, p. 86). Likewise May (1939) noted, "In England good practice is derived chiefly from the individual's strict, unwritten ethical code and self-imposed discipline and from his voluntary restriction of conduct well within the confines of the technical law. Etiquette compensates for the absence of legally accountable trusteeship" (p. 496).

32 Titled directors were frequently used as methods of upholding corporate reputations. Florence (1953) reports that there were 654 English peers active in city firms in 1932. "One well-known insurance company in 1937 had among sixteen directors, three knights, one baron, one marquis, one earl and two dukes" (p 245). Likewise, May (1939) reports that of 654 British peers, 189 of them were directors of companies and held 562 directorates between them.

${ }^{33}$ For example, in the case of the acquisition of Lamert by De La Rue, the number of target shareholders exceeded 1000.

${ }^{34}$ Four of the 27 mergers came from the 1900 sample, as reported in Panel A of Table A4, 15 from Hannah's (1976) sample as reported in Panel B of Table A4 and 8 additional acquisitions were found during the course of the exercise.
} 
for example, Dyck and Zingales (2004) estimate private benefits of 9.5\% for Germany using the measure employed by Barclay and Holderness (1989).

Finally, we examined other equity issues by companies in our sample for purposes other than acquisitions. We find that where a company's equity is traded, shares are usually offered to existing shareholders pro rata. In the two exceptions, we compare the issue prices with market prices to determine if insiders received new shares at preferential prices. We found that in one case, General Electric later Marconi, the insiders purchased shares at a $6 \%$ discount but that the issue represented less than $5 \%$ of outstanding equity. In the other case, Bleachers Association, later Whitecroft, insiders paid a small premium.

While it is impossible to say whether insiders received benefits not reflected in transaction prices, ${ }^{35}$ it appears that the U.K. did not follow the Continental European practice of two-tier equity offerings, purchasing a block of shares at one price and leaving a substantial residual minority on the market at another. An equal price treatment of shareholders prevailed in the first half of the $20^{\text {th }}$ century in the U.K., even in the absence of a formal regulatory rule to that effect.

\subsection{Distance, medium of exchange and survivorship of target directors}

We conjecture that where equity was the medium of exchange then the directors of the target firm played a particularly important role in sustaining the trust of the target shareholders. Likewise, we argue that their advice was particularly critical where the acquiring and target firms were geographically separated and where reliance could not therefore be placed on the proximity of the directors of the acquiring firm. We would therefore expect that the chairman of the target was more likely to join the board of the bidder as the proportion of equity in the medium of exchange and the distance between the acquiring and target firm increased.

We obtained data on 27 of the mergers reported in Table A7 including the names of board members before and after the merger, the distance between the acquirer's and the target company's address, the means of payment, and the size and

\footnotetext{
${ }^{35}$ At the company meetings discussing the amalgamation of Alfred Hickman and Stewart and Lloyds, Mr. J.G. Stewart, chairman of Stewart and Lloyds, said: "I have been reminded, only a few hours ago, that I might be asked today at this meeting whether the directors have been given any consideration in any shape or form whatever to enable them to see their way to advise this amalgamation. I can only say this, gentlemen, that not one farthing, directly or indirectly, has been or will be paid to anybody whatever, either on the staff or on the Board of either of these companies, other than one share in Stewarts and Lloyds and 7s 6d in cash per share for whatever shares they hold.” FT Monday 30 August 1920.
} 
industry of acquirer and target. In 16 out of 27 cases, we find that the chairman of the target joins the board of the bidder. In addition, there is an average survivorship of $70 \%$ of the directors of the target board. In comparison, a study of 35 successful hostile takeovers in 1985 and 1986 by Franks and Mayer (1996) reports 90\% of directors being replaced within two years of the bid. The equivalent figure for 35 accepted bids was $50 \%$. Board turnover was appreciably lower in the first half of the century than it was in both accepted and hostile bids in the second.

In columns 1 and 2 of Panel B of Table 10, we report the results of a probit regression of chairman survivorship on distance between target and bidder's city of incorporation, the proportion of equity in the transaction, the target bid premium and the ratio of the book value of equity of the target firm to that of the bidder. ${ }^{36}$ We find that the likelihood of the target chairman joining the board of the bidder increases in the distance between the target and the bidder. Without the other variables, the coefficient is significant at the $10 \%$ level. It becomes significant at the $5 \%$ level when we introduce other variables. A 10-percent increase in distance between the merging firms is associated with a $7.7 \%$ increase in the probability of survivorship of the target chairman. Equity as a percentage of the value of the transaction is positive and significant: the higher the proportion of equity in the transaction, the more likely is the chairman to sit on the bidder's board, reflecting a greater need to sustain relations of trust. A one percent increase in the share of equity is associated with a $2.2 \%$ increase in the probability of survivorship of the target chairman.

In the last two columns we report the results of a tobit regression of the proportion of the target directors who survive the merger on the same set of explanatory variables. We find that the proportion of equity in the transaction is positive and significantly related to board survivorship. A ten percent increase in the share of equity is associated with a $6.6 \%$ increase in the proportion of the target directors surviving. Distance is also positively related to survivorship but the coefficient is not significant. This suggests that the promotion of the chairman to the merged board is the mechanism by which trust is upheld at distance, and that the retention of other members of the board is also important where target shareholders retain an equity interest in the merged firm.

\footnotetext{
${ }^{36}$ Data on chairman turnover and bid premia comes from Franks, Mayer and Rossi (2005).
} 


\section{$7 \quad$ Conclusions}

This paper reports the first long-run analysis of the evolution of law, finance and ownership of corporations. It records that the mother of common law enjoyed a flourishing equity market from the start of the twentieth century. Equity issues were prevalent, takeovers widespread, local stock markets active and ownership dispersed. But the relation between law and finance is not straightforward. Common law did not promote investor protection: by any measure, investor protection was weak until the end of the 1920s and strong only in the second half of the century. Capital markets flourished in spite of weak investor protection.

How could this be possible? The answer we give is that equity markets developed on the basis of informal relations of trust rather than formal systems of regulation. Shareholders had little recourse in courts but much influence in the communities and local markets of which they and their firms were a part. Even as it became dispersed, ownership remained geographically concentrated and directors were concerned to maintain their reputations amongst local investors. All shareholders including insiders sold their shares to acquiring firms at the same price and directors of target firms were frequently promoted to the boards of merged firms. Eventually, as local relations of trust became harder to sustain then formal systems of regulation emerged to substitute for them.

Was the UK an isolated case? Franks, Mayer and Wagner (2005) and Franks, Mayer and Miyajima (2005) record surprisingly active stock markets in Germany and Japan at the start of the twentieth century, with a large number of listed companies and large amounts of equity issued. Again it is not easy to attribute the flourishing capital markets to formal systems of regulation. Investor protection was weak in both countries as it was in the UK. But there were differences. Takeover waves were less in evidence in both countries and the purpose to which new equity was put was primarily to finance internal rather than external expansion.

The success of equity markets in all three countries appears to have had more to do with informal relations of trust than formal systems of regulation. However, the institutional arrangements that fostered trust were not the same. Local stock markets were prevalent in Germany but not in Japan. Banks played a more critical role in the development of stock markets at the beginning of the century in Germany than in either Japan or the UK. Individual promoters of shares took on a more active role in the oversight and management of firms in Japan than in the UK. Different mechanisms 
therefore evolved to establish the basis of trust on which equity markets and finance could develop. It is to an understanding of these that the study of both development finance and the history of developed capital markets might turn. 


\section{References}

Banfield, Edward C., 1958. The moral basis of a backward society. New York: Free Press.

Barclay, Michael, and Clifford Holderness, 1989. Private benefits of control of public corporations. Journal of Financial Economics 25, 371-395.

Becht, Marco, and Colin P. Mayer, 2001. "Introduction” in Barca, Fabrizio, and Marco Becht, (eds.), 2001, The control of corporate Europe. Oxford University Press, Oxford.

Beck, Thorsten, Asli Demirgüç-Kunt, and Ross Levine, 2003. Law and finance: Why does legal origin matter? Journal of Comparative Economics 31, 653-675.

Berle, Adolf A., and Gardiner C. Means, 1932. The modern corporation and private property. Macmillan, New York: NY.

Cairncross, Alec K., 1953. Home and foreign investment, 1870-1913. Cambridge, U.K.

Cairncross, Alec K., 1958. The English capital market before 1914. Economica 25, 142-146.

Chandler, Alfred D., 1990. Scale \& scope: The dynamics of industrial capitalism. Harvard University Press, Cambridge: MA.

Cheffins, Brian, 2002. Putting Britain on the Roe map: The emergence of the Berle-Means corporation in the United Kingdom, in J.A. McCahery et al. (eds.), Corporate governance regimes: Convergence and diversity, Oxford: Oxford University Press, 147-72.

Code Holland, R. H., and John N. Werry, (eds.), 1932. Poley's law and practice of the stock exchange. Sir Isaac Pitman \& Sons, London.

Coffee, John C. Jr, 2001. The rise of dispersed ownership: The role of law in the separation of ownership and control. Mimeo, Columbia University School of Law.

Cohen Committee Report, 1945. Report of the committee on company law amendment. Cmd 6659, HMSO, London.

Coleman, James S., 1990. Foundations of social theory. Cambridge, MA: Harvard University Press.

Davies, Paul L. (ed.), 1979. Gower's principles of modern company law (4th ed). Stevens \& Sons, London.

Degryse, Hans and Steven Ongena, 2005. Distance, lending relationships and competition. Journal of Finance 60, 231-266.

Dyck, Alexander, and Luigi Zingales, 2004. Private benefits of control: An international comparison, Journal of Finance 59, 537-600.

Florence, P. Sargant, 1947. Proceedings of the First Ordinary Meeting of the Session, 1946-47, held on November 27th, 1946, The President, The Rt. Hon. Lord Woolton, P. C., C. H., in the Chair. Journal of the Royal Statistical Society 110, 1-26.

Florence, P. Sargant, 1953. The logic of British and American industry. Routledge \& Kegan Paul, London.

Florence, P. Sargant, 1961. Ownership, control and success of large companies: An analysis of English industrial structure and policy 1936-1951. Sweet and Maxwell, London.

Franks, Julian R., and Robert S. Harris, 1989. Shareholder wealth effect of corporate takeovers. The U.K. experience 1955-1985. Journal of Financial Economics 23, 225-249. 
Franks, Julian R., and Colin P. Mayer, 2001. Ownership and control of German corporations. Review of Financial Studies 14, 943-977.

Franks, Julian R., and Colin P. Mayer, 1998. Bank control, takeovers and corporate governance in Germany. Journal of Banking and Finance 22, 1385-1403.

Franks, Julian R., and Colin P. Mayer, 1996. Hostile takeovers and the correction of managerial failure. Journal of Financial Economics 40, 163-181.

Franks, Julian R., Colin P. Mayer and Luc Renneboog, 2001. Who disciplines management in poorly performing companies? Journal of Financial Intermediation 10, 209-248.

Franks, Julian R., Colin P. Mayer and Hideaki Miyajima, 2005. Evolution of ownership and control in Japan. Mimeo

Franks, Julian R., Colin P. Mayer and Stefano Rossi, 2005. Spending less time with the family: The decline of family ownership in the U.K., in Morck, Randall K., (ed.) A History of Corporate Governance around the World: Family Business Groups to Professional Managers, NBER and University of Chicago Press, forthcoming.

Franks, Julian R., Colin P. Mayer and Hannes Wagner, 2005. The origins of the German corporation Finance, ownership and control. Mimeo.

Gomes, Armando, 2000. Going public without governance: Managerial reputation effects. Journal of Finance 55, 615-646.

Goshen, Zohar, 1998. Voting in conflicts of interests in corporate law and minority protection. Mimeo.

Greene Committee Report, 1925. The company law amendment committee report. Cmd 2657, HMSO, London.

Greif, Avner, 1993. Contract enforceability and economic institutions in early trade: The Maghribi traders coalition. American Economic Review 83, 525-548.

Grinblatt, Mark and Matti Keloharju, 2001. How distance, language and culture influence stockholdings and trades. Journal of Finance 56, 1053-1073.

Grossman, Sanford and Oliver Hart, 1986. The costs and benefits of ownership: A theory of vertical and lateral integration. Journal of Political Economy 94, 691-719.

Guiso, Luigi, Paola Sapienza, and Luigi Zingales, 2004. Does local financial development matter? Quarterly Journal of Economics 119, 929-969.

Guiso, Luigi, Paola Sapienza, and Luigi Zingales, 2005. Cultural biases in economic exchange. Mimeo, University of Chicago.

Hannah, Leslie, 1974a. Mergers in British manufacturing industry 1880-1918. Oxford Economic Papers $26,1-20$

Hannah, Leslie, 1974b. Takeover bids in Britain before 1950: An exercise in business 'pre-history'. Business History 16, 65-77.

Hannah, Leslie, 1976. The rise of the corporate economy. Methuen, London.

Hart, Oliver and John Moore, 1990. Property rights and the theory of the firm. Journal of Political Economy, 98, 1119-1158.

Hart, Peter and Sig Prais, 1956. The analysis of business concentration: a statistical approach. Journal of the Royal Statistical Society 119, 150-191. 
Hoffman, Leonard H. H., 1999. Foreword to Hollington, Robin, 1999, Minority shareholders' rights. Sweet and Maxwell, London.

Holderness, Clifford, Randall Kroszner, and Dennis Sheehan, 1999. Were the good old days that good? Changes in managerial stock ownership since the Great Depression. Journal of Finance 54, 435-469.

Hong, Harrison, Jeffrey D. Kubik, and Jeremy C. Stein, 2004. Social interactions and stock-market participation. Journal of Finance 59, 137-163.

Jenkinson, Tim, and Alexander Ljungqvist, 2001. The role of hostile stakes in German corporate governance. Journal of Corporate Finance 7, 397-446.

Kreps, David, and Robert Wilson, 1982. Reputation and imperfect information. Journal of Economic Theory 27, 253-279.

La Porta, Rafael, Florencio Lopez-de-Silanes, Andrei Shleifer, and Robert W. Vishny, 1997. Legal determinants of external finance. Journal of Finance 52, 1131-1150.

La Porta, Rafael, Florencio Lopez-de-Silanes, Andrei Shleifer, and Robert W. Vishny, 1998. Law and finance. Journal of Political Economy 101, 678-709.

La Porta, Rafael, Florencio Lopez-de-Silanes and Andrei Shleifer, 2004. What works in securities laws? Journal of Finance, forthcoming.

Larner, Robert J., 1966. Ownership and control in the 200 largest nonfinancial corporations, 1929 and 1963. American Economic Review 56, 777-787.

Lavington, Frederick, 1921. The English capital market. Methuen, London.

Mauro, Paolo, and Yishay Yafeh, 2003. The corporation of foreign bondholders. IMF working paper.

May, Wilfred, 1939. Financial regulation abroad: The contrasts with American technique. Journal of Political Economy 47, 457-496.

Meeks, Geoffrey and Geoffrey Whittington, 1975. Giant companies in the United Kingdom, 1948-69. The Economic Journal 85, 824-843.

Michie, Ranald C., 1999. The London stock exchange: A history. Oxford University Press, Oxford.

Milgrom, Paul, and John Roberts, 1982. Predation, reputation and entry deterrence. Journal of Economic Theory 27, 280-312.

Morgan, E. Victor, and William A. Thomas, 1962. The stock exchange: Its history and functions. Elek Books, London.

Nibler, Marcus F., 1996. Bank control and corporate performance in Germany: The evidence, $\mathrm{PhD}$ Thesis, St John's College Cambridge.

North, Douglass C., and Barry R. Weingast, 1989. Constitutions and commitment: The evolution of institutional governing public choice in seventeenth-century England. Journal of Economic History 49, 803-832.

Nyman, Steve and Aubrey Silberston, 1978. The ownership and control of industry. Oxford Economic Papers 30, 74-101.

Paish, Frank W., 1951. The London new issue market. Economica 28, 1-17.

Petersen, Mitchell A. and Raghuram G. Rajan, 1994. The benefits of lending relationships: Evidence from small business data. Journal of Finance 49, 3-37. 
Petersen, Mitchell A. and Raghuram G. Rajan, 2002. Does distance still matter? The information revolution in small business lending. Journal of Finance, 57, 2533-2570.

Roberts, Richard, 1992. Regulatory responses to the rise of the market for corporate control in Britain in the 1950s. Business History 34, 183-200.

Rajan, Raghuram G., and Luigi Zingales, 2003. The great reversals: The politics of financial development in the $20^{\text {th }}$ Century. Journal of Financial Economics, 69, 5-50.

Roe, Mark J., 1994. Strong managers, weak owners: The political roots of American corporate finance. Princeton University Press, Princeton: NJ.

Rossi, Stefano, and Paolo Volpin, 2004. Cross-country determinants of mergers and acquisitions. Journal of Financial Economics 74, 277-304.

Schwabe, Walter S., and G. A. H. Branson, 1913. A treatise on the laws of the stock exchange. Butterworth and Co., London.

Sealy, Leonard 1967. The director as a trustee, Cambridge Law Journal, 83-103

Sealy, Leonard, 1984. Company law and commercial reality, London.

Spagnolo, Giancarlo, 1999. Social relations and cooperation in organizations. Journal of Economic Behavior and Organization 38, 1-25.

Thomas, William A., 1973. The provincial stock exchanges. Frank Cass, London.

White, Halbert S., 1980. A heteroskedasticity-consistent covariance matrix estimator and a direct test for heteroskedasticity. Econometrica 48, 817-838. 


\section{Table 1 - Key developments in the regulation of U.K. capital markets}

Panel A of the table reports the evolution over time of the anti-director rights index defined by La Porta, Lopez-de-Silanes, Shleifer and Vishny (1998). "The index is formed by adding 1 when: (1) the country allows shareholders to mail their proxy vote to the firm; (2) shareholders are not required to deposit their shares prior to the General Shareholders' Meeting; (3) cumulative voting or proportional representation of minorities in the board of directors is allowed; (4) an oppressed minorities mechanism is in place; (5) the minimum percentage of share capital that entitles a shareholder to call for an Extraordinary Shareholders' Meeting is less than or equal to 10 percent (the sample median); or (6) shareholders have preemptive rights that can only be waived by a shareholders' vote. The index ranges from 0 to 6." (LLSV (1998) page 1123).

Panels B, C and D report the evolution of the new La Porta, Lopez-de-Silanes and Shleifer (2004) indices of disclosure requirements, liability standards and public enforcement. These indices combine information on whether prospectuses had to be issued, whether specific categories of information had to be disclosed in the prospectus (i.e. director compensation, share ownership, inside ownership, irregular contracts, transactions between related parties), liability standards (for the issuer and directors, distributors and accountants), and public enforcement (the characteristics of the supervisors of the securities markets, their investigative powers and sanctions).

Panel A - Index of anti-director rights over time using La Porta, Lopez-de-Silanes, Shleifer and Vishny's (1998) classification

\begin{tabular}{|c|c|c|}
\hline Score & Period & Description of anti director rights provisions \\
\hline 1 & $1843-1947$ & Shares cannot be blocked before meeting (always been in place). \\
\hline 3 & $1948-1979$ & $\begin{array}{l}\text { Proxy by mail allowed and percentage of share capital to call an extraordinary shareholders meeting } \\
<=10 \% \text {, Companies Act 1948, Sections } 136 \text { and 132, respectively. }\end{array}$ \\
\hline 4 & $1980-1984$ & Preemptive Rights to new issues, Companies Act 1980 Section 17. \\
\hline 5 & 1985 - today & Oppressed minorities, Section 459 of Companies Act 1985. \\
\hline
\end{tabular}

Panel B - Index of disclosure requirements over time using La Porta, Lopez-de-Silanes and Shleifer (2004) classification

\begin{tabular}{lll}
\hline \hline Score & Period & Description of disclosure requirements \\
\hline 0 & $1843-1928$ & $\begin{array}{l}\text { A prospectus is not required, by law, by the London Stock Exchange or Provincial Stock Exchanges. } \\
\text { Shares can be traded and capital can be raised informally (i.e. without a prospectus), provided the } \\
\text { issuer files a statement with the registrar. Section 1 of Companies Act 1907, and Section 4 of } \\
\text { Companies Act 1900. } \\
\text { A prospectus is required by Section 35 of the Companies Act 1929. In the prospectus, the issuer has } \\
\text { to disclose the compensation, inside ownership of each director, as well as all material contracts } \\
\text { made by the issuer outside the course of the business, and all transactions in which related parties } \\
\text { have, or will have, an interest. } 4^{\text {th }} \text { Schedule of the Companies Act 1929. } \\
\text { Requirement of disclosure of the name and ownership stake of each shareholder who, directly or } \\
\text { indirectly, controls ten percent or more of the issuer's voting securities. Section 33 of Companies } \\
\text { Act 1967. }\end{array}$ \\
\hline \hline
\end{tabular}

Panel C - Index of liability standards over time using La Porta, Lopez-de-Silanes and Shleifer's (2004) classification

\begin{tabular}{|c|c|c|}
\hline Score & Period & Description of liability standards \\
\hline 0 & $1889-1928$ & $\begin{array}{l}\text { Rule in Derry vs. Peek } 188 \text { stated that fraud had to be demonstrated. Section } 3 \text { of the Directors' } \\
\text { Liability Act } 1890 \text { shifted the burden of proof onto directors. Directors' Liability Act of } 1907 \text { and } \\
\text { the Companies Act did not require issue of prospectus if registration of some prospectus information } \\
\text { occurred. Also directors were immune from a lawsuit for practical purposes if the articles of } \\
\text { association included provisions excusing negligence- LQR, January 1935: "The } 1929 \text { Act also } \\
\text { stopped or rendered useless another practice which for some years rendered the directors of a } \\
\text { company practically immune from liability to compensate their shareholders for losses caused or } \\
\text { contributed to by the negligence of the directors." }\end{array}$ \\
\hline 0.333 & $1929-1947$ & $\begin{array}{l}\text { Section 35(3) of the } 1929 \text { Companies Act required a prospectus and demonstration that the investor } \\
\text { relied on the prospectus but made negligence sufficient for director liability. Directors could no } \\
\text { longer exclude negligence from the articles of association. }\end{array}$ \\
\hline 0.667 & 1948 - today & $\begin{array}{l}\text { Section } 44 \text { of the } 1948 \text { Companies Act made directors liable for untrue statements even if they were } \\
\text { not negligent. }\end{array}$ \\
\hline
\end{tabular}

Panel D - Index of public enforcement over time using La Porta, Lopez-de-Silanes and Shleifer's (2004) classification

\begin{tabular}{lll}
\hline \hline Score & Period & Description of public enforcement provisions \\
\hline 0 & $1843-1985$ & No public enforcement body exists. Financial frauds handled by the police fraud department. \\
0.745 & $1986-$ today & $\begin{array}{l}\text { Financial Services Act creates Self Regulatory Organizations, later centralized into the Financial } \\
\text { Services Authority. }\end{array}$ \\
\hline \hline
\end{tabular}


Table 2 - Annual growth in total equity capital

This table reports annual growth in total ordinary equity capital in the sample firms, and its use in financing acquisitions and internal investment. Total ordinary equity is the number of issued ordinary shares. Growth in total ordinary equity is normalized to exclude the influence of capitalization of reserves. Acquisitions are classified as being purchased with shares or cash raised from equity issues based upon the public announcement or prospectus. Equity issued for purposes other than acquisition is disaggregated into equity offerings to existing shareholders and offers to new subscribers, including IPOs. Panel A refers to the complete 1900 sample, Panel B to the 1960 sample and Panel C reports t-statistics of differences in means between the two samples (1960 sample minus 1900 sample); the comparison is with the first four decades of each sample. Panels D and E report t-statistics of differences of the 1960 sample with the surviving and non-surviving companies in the 1900 sample, respectively. Superscript letters a, b, c indicate significance at 1, 5 and 10 percent levels, respectively.

Panel A: Annual growth in total ordinary capital and the factors contributing to this, complete 1900 sample

\begin{tabular}{lccccrrr}
\hline & \multicolumn{3}{c}{ Annual growth in total ordinary capital (\%) } & \multicolumn{4}{c}{ Use of equity issues (\%) } \\
\hline & Mean & Median & N. Obs. & Acquisitions made with: & \multicolumn{3}{c}{ Internal investment: } \\
\cline { 5 - 8 } & & & Shares & Cash & $\begin{array}{c}\text { From existing } \\
\text { shareholders }\end{array}$ & $\begin{array}{c}\text { From new } \\
\text { shareholders }\end{array}$ \\
\hline $1900-1910$ & 35.57 & 2.17 & 40 & 97.73 & 0.00 & 0.17 & 2.10 \\
$1910-1920$ & 2.31 & 0.00 & 38 & 25.86 & 11.21 & 62.93 & 0.00 \\
$1920-1930$ & 1.56 & 0.00 & 37 & 44.87 & 8.33 & 38.46 & 8.33 \\
$1930-1940$ & 1.00 & 0.00 & 33 & 16.00 & 20.00 & 64.00 & 0.00 \\
$1940-1950$ & 0.95 & 0.00 & 31 & 1.02 & 0.00 & 78.57 & 20.41 \\
$1950-1960$ & 3.07 & 0.00 & 25 & 22.80 & 16.61 & 60.59 & 0.00 \\
$1960-1970$ & 4.99 & 1.83 & 23 & 31.08 & 0.00 & 34.36 & 34.56 \\
$1970-1980$ & 2.23 & 2.60 & 22 & 16.14 & 14.80 & 69.06 & 0.00 \\
$1980-1990$ & 3.61 & 1.84 & 22 & 24.31 & 0.00 & 57.46 & 18.23 \\
$1990-2000$ & 3.56 & 2.27 & 20 & 12.92 & 4.78 & 69.66 & 12.64 \\
\hline Mean & 10.60 & & & 68.27 & 2.72 & 22.38 & 6.64 \\
\hline \hline
\end{tabular}

Panel B: Annual growth in total ordinary capital and the factors contributing to this, 1960 sample

\begin{tabular}{lccccccc}
\hline & \multicolumn{3}{c}{ Annual growth in total ordinary capital (\%) } & \multicolumn{4}{c}{ Use of equity issues (\%) } \\
\hline & & & & \multicolumn{2}{c}{ Acquisitions made with: } & \multicolumn{2}{c}{ Internal investment: } \\
\cline { 5 - 8 } & Mean & Median & N. Obs. & Shares & Cash & $\begin{array}{c}\text { From existing } \\
\text { shareholders }\end{array}$ & $\begin{array}{c}\text { From new } \\
\text { shareholders }\end{array}$ \\
\hline $1960-1970$ & 85.67 & 44.47 & 20 & 43.23 & 23.27 & 12.51 & 20.99 \\
$1970-1980$ & 3.31 & 1.63 & 20 & 43.66 & 5.14 & 22.09 & 29.11 \\
$1980-1990$ & 4.08 & 0.00 & 20 & 53.04 & 7.48 & 29.47 & 10.01 \\
$1990-2000$ & 2.87 & 0.00 & 20 & 12.34 & 4.60 & 18.87 & 64.19 \\
\hline Mean & 22.14 & & & 42.83 & 21.22 & 13.91 & 22.04 \\
\hline \hline
\end{tabular}

Panel C: 1960 vs. 1900 (complete sample) - Tests of means (t-statistics)

\begin{tabular}{lccccc}
\hline \hline & First decade & Second decade & Third decade & Fourth decade & Overall \\
\hline Growth & $2.29^{\mathrm{b}}$ & 0.63 & 1.33 & 1.65 & $1.99^{\mathrm{b}}$ \\
Shares Acquisitions & 0.48 & $1.69^{\mathrm{c}}$ & 1.18 & 0.73 & 0.46 \\
Cash Acquisitions & 1.61 & -0.15 & 0.08 & -0.25 & 1.52 \\
Internal Investment & $1.74^{\mathrm{c}}$ & -0.06 & 1.31 & $1.75^{\mathrm{c}}$ & $1.75^{\mathrm{c}}$ \\
\hline \hline
\end{tabular}

Panel D: 1960 vs. 1900 (survivors only) - Tests of means (t-statistics)

\begin{tabular}{lccccr}
\hline & First decade & Second decade & Third decade & Fourth decade & Overall \\
\hline Growth & 1.36 & -0.36 & 0.66 & 0.84 & 1.22 \\
Shares Acquisitions & -0.38 & 0.87 & 0.62 & 0.26 & -0.26 \\
Cash Acquisitions & 1.13 & -0.56 & 1.00 & -0.57 & 1.10 \\
Internal Investment & $1.93^{\mathrm{c}}$ & -0.71 & 0.41 & 1.04 & $1.85^{\mathrm{c}}$ \\
\hline \hline
\end{tabular}

Panel E: 1960 vs. 1900 (non-survivors only) - Tests of means (t-statistics)

\begin{tabular}{lccccc}
\hline & First decade & Second decade & Third decade & Fourth decade & Overall \\
\hline Growth & $2.36^{\mathrm{b}}$ & $2.80^{\mathrm{a}}$ & 1.31 & $1.98^{\mathrm{c}}$ & $2.00^{\mathrm{b}}$ \\
Shares Acquisitions & 1.48 & $2.30^{\mathrm{b}}$ & 1.16 & 1.04 & 1.36 \\
Cash Acquisitions & 1.13 & 1.24 & -0.45 & 0.80 & 1.05 \\
Internal Investment & 0.93 & 1.64 & $1.91^{\mathrm{c}}$ & $1.94^{\mathrm{c}}$ & 0.97 \\
\hline \hline
\end{tabular}


Table 3 - Evolution of ownership

This table reports the evolution of ownership over time for our sample. Ownership is defined as the minimum number of shareholders necessary to pass a threshold of $25 \%$ of cash flow rights, and is computed for all shareholders, for directors alone, and for outsiders, respectively. Frequency is the number of companies in which directors and outsiders pass the $25 \%$ threshold alone. Panel A refers to the complete 1900 sample, Panel B to the 1960 sample and Panel C to t-statistics of differences in means between the two samples (1960 minus 1900). Panels D and E report t-statistics of differences of the 1960 sample from the surviving and non-surviving companies in the 1900 sample, respectively. Superscript letters a, b, c indicate significance at 1,5 and 10 percent levels, respectively.

Panel A: Evolution of ownership - complete 1900 sample

\begin{tabular}{lrrrrrrr}
\hline \hline & \multicolumn{2}{c}{ All shareholders } & \multicolumn{2}{c}{ Directors } & \multicolumn{2}{c}{ Outsiders } \\
\hline & Mean & Median & Mean & Frequency & Mean & Frequency N. Obs. \\
1900 & 2.35 & 1.00 & 1.77 & 39 & 15.40 & 10 & 40 \\
1910 & 6.93 & 1.50 & 2.80 & 30 & 19.15 & 26 & 40 \\
1920 & 9.92 & 2.00 & 1.96 & 26 & 23.93 & 27 & 37 \\
1930 & 14.78 & 3.50 & 2.24 & 21 & 28.93 & 28 & 36 \\
1940 & 14.84 & 5.00 & 2.00 & 13 & 22.00 & 23 & 32 \\
1950 & 21.13 & 7.00 & 3.17 & 12 & 27.25 & 24 & 30 \\
1960 & 24.83 & 10.00 & 4.00 & 8 & 31.65 & 20 & 24 \\
1970 & 51.95 & 11.00 & 3.00 & 8 & 57.57 & 21 & 23 \\
1980 & 57.86 & 8.00 & 1.80 & 5 & 61.24 & 21 & 22 \\
1990 & 45.76 & 4.00 & 2.00 & 2 & 48.33 & 21 & 21 \\
2000 & 48.45 & 3.00 & 1.67 & 3 & 53.58 & 19 & 20 \\
\hline Mean & 22.49 & & 2.33 & & 35.12 & & \\
\hline \hline
\end{tabular}

Panel B: Evolution of ownership - 1960 sample

\begin{tabular}{rrrrrrrr}
\hline & \multicolumn{2}{c}{ All shareholders } & \multicolumn{2}{c}{ Directors } & \multicolumn{2}{c}{ Outsiders } \\
\hline & Mean & Median & Mean & Frequency & Mean & Frequency N. Obs. \\
\hline 1960 & 1.10 & 1.00 & 1.10 & 20 & 0.00 & 0 & 20 \\
1970 & 23.55 & 2.00 & 1.23 & 13 & 23.25 & 16 & 20 \\
1980 & 15.05 & 1.00 & 2.08 & 13 & 20.12 & 17 & 20 \\
1990 & 10.10 & 4.50 & 1.50 & 8 & 10.90 & 20 & 20 \\
2000 & 3.85 & 3.00 & 1.40 & 5 & 5.25 & 20 & 20 \\
\hline Mean & 9.09 & & 1.42 & & 14.40 & & \\
\hline \hline
\end{tabular}

Panel C: 1960 vs. 1900 (complete sample) - Tests of means (t-statistics)

\begin{tabular}{lcccccc}
\hline & 1960 vs. 1900 & 1970 vs. 1910 & 1980 vs. 1920 & 1990 vs. 1930 & 2000 vs. 1940 & Overall \\
\hline All shareholders & -1.29 & 0.95 & 0.50 & -0.60 & -1.59 & -0.10 \\
\hline \hline Panel D: 1960 vs. 1900 (survivors only) - Tests of means (t-statistics) & & & \\
\hline \hline & 1960 vs. 1900 & 1970 vs. 1910 & 1980 vs. 1920 & 1990 vs. 1930 & 2000 vs. 1940 & Overall \\
\hline All shareholders & -1.53 & 0.55 & 0.23 & -0.55 & $-2.04^{\text {b }}$ & -0.23 \\
\hline \hline Panel E: 1960 vs. 1900 (non-survivors only) - Tests of means (t-statistics) & & & \\
\hline \hline & 1960 vs. 1900 & 1970 vs. 1910 & 1980 vs. 1920 & 1990 vs. 1930 & 2000 vs. 1940 & Overall \\
\hline All shareholders & -1.64 & 0.83 & 0.52 & -0.50 & -1.29 & 0.08 \\
\hline \hline
\end{tabular}


Table 4 - Alternative measures of ownership concentration

This table reports directors' shareholdings, and alternative measures of ownership concentration. The measures are C3, the aggregate holdings of the three largest shareholders, C3i, the aggregate holdings of the three largest inside shareholders (directors), C3o, the aggregate holdings of the three largest outside shareholders, C5, the aggregate holdings of the five largest shareholders, and the Herfindahl index. Panel A refers to the complete 1900 sample, Panel B refers to the 1960 sample and Panel C reports t-statistics of differences in means across the two samples (1960 minus 1900). Panels D and E report t-statistics of differences of the 1960 sample with the surviving and non-surviving companies in the 1900 sample, respectively. Superscript letters a, b, c indicate significance at 1, 5 and 10 percent levels, respectively.

Panel A: Complete 1900 sample

\begin{tabular}{|c|c|c|c|c|c|c|c|}
\hline & Directors & & $\mathrm{C} 3$ & & $\mathrm{C} 5$ & Herfindahl & N. Obs. \\
\hline & & $\mathrm{C} 3$ & $\mathrm{C} 3 \mathrm{i}$ & $\mathrm{C} 3 \mathrm{o}$ & & & \\
\hline 1900 & 92.76 & 64.39 & 62.87 & 2.81 & 72.96 & 0.30827 & 40 \\
\hline 1910 & 53.61 & 52.86 & 47.85 & 9.00 & 60.15 & 0.24839 & 40 \\
\hline 1920 & 49.02 & 46.30 & 44.01 & 6.04 & 51.33 & 0.21858 & 37 \\
\hline 1930 & 37.42 & 39.55 & 34.85 & 7.77 & 43.85 & 0.18591 & 36 \\
\hline 1940 & 37.69 & 40.58 & 35.13 & 8.20 & 44.13 & 0.22584 & 32 \\
\hline 1950 & 27.60 & 33.83 & 27.35 & 9.29 & 37.88 & 0.16831 & 30 \\
\hline 1960 & 29.85 & 27.44 & 21.89 & 8.68 & 32.92 & 0.09678 & 24 \\
\hline 1970 & 21.40 & 26.05 & 18.90 & 11.64 & 30.56 & 0.08344 & 23 \\
\hline 1980 & 18.53 & 25.95 & 17.55 & 11.07 & 30.04 & 0.08649 & 22 \\
\hline 1990 & 13.23 & 31.37 & 11.19 & 21.49 & 36.83 & 0.09853 & 21 \\
\hline 1900 & 10.45 & 30.36 & 10.39 & 23.80 & 35.35 & 0.06684 & 20 \\
\hline Mean & 42.40 & 40.72 & 33.99 & 9.73 & 46.11 & 0.18115 & \\
\hline
\end{tabular}

Panel B: 1960 sample

\begin{tabular}{rrrrrrrr}
\hline & Directors & \multicolumn{7}{c}{ C3 } & & C5 & Herfindahl & N. Obs. \\
\hline & & C3 & C3i & C3o & & & \\
1960 & 100.00 & 92.29 & 91.97 & 0.00 & 93.54 & 0.53588 & 20 \\
1970 & 46.96 & 51.84 & 46.60 & 10.56 & 56.72 & 0.28105 & 20 \\
1980 & 35.27 & 40.74 & 30.83 & 13.42 & 45.01 & 0.12425 & 20 \\
1990 & 20.49 & 33.28 & 18.78 & 19.39 & 39.84 & 0.07155 & 20 \\
2000 & 14.94 & 32.64 & 13.54 & 24.03 & 39.94 & 0.06734 & 20 \\
\hline Mean & 43.53 & 50.16 & 40.34 & 13.56 & 55.01 & 0.21601 & \\
\hline \hline
\end{tabular}

Panel C: 1960 vs. 1900 (complete sample) - Tests of means (t-statistics)

\begin{tabular}{lccccccc}
\hline \hline & 1960 vs. 1900 & 1970 vs. 1910 & 1980 vs. 1920 & 1990 vs. 1930 & 2000 vs. 1940 & Overall \\
\hline Directors & 1.46 & -0.66 & -1.42 & $-1.93^{\mathrm{c}}$ & $-2.51^{\mathrm{b}}$ & $-2.01^{\mathrm{b}}$ \\
C3 & $3.47^{\mathrm{a}}$ & -0.11 & -0.64 & -0.76 & -0.94 & 0.20 \\
C3i & $3.52^{\mathrm{a}}$ & -0.13 & -1.44 & $-1.86^{\mathrm{c}}$ & $-2.38^{\mathrm{b}}$ & -1.15 \\
C3o & $-2.07^{\mathrm{b}}$ & 0.42 & $2.96^{\mathrm{a}}$ & $4.29^{\mathrm{a}}$ & $5.20^{\mathrm{a}}$ & $5.01^{\mathrm{a}}$ \\
C5 & $2.70^{\mathrm{a}}$ & -0.37 & -0.71 & -0.48 & -0.49 & -0.05 \\
Herfindahl & $2.83^{\mathrm{a}}$ & 0.36 & -1.29 & -1.65 & $-1.97^{\mathrm{c}}$ & -0.62 \\
\hline \hline
\end{tabular}

Panel D: 1960 vs. 1900 (survivors only) - Tests of means (t-statistics)

\begin{tabular}{lccccccc} 
& 1960 vs. 1900 & 1970 vs. 1910 & 1980 vs. 1920 & 1990 vs. 1930 & 2000 vs. 1940 & Overall \\
\hline Directors & 1.44 & -0.67 & -1.32 & $-1.71^{\mathrm{c}}$ & $-1.88^{\mathrm{c}}$ & $-1.79^{\mathrm{c}}$ \\
C3 & $2.84^{\mathrm{a}}$ & -0.19 & -0.80 & -0.55 & -0.18 & 0.33 \\
C3i & $3.33^{\mathrm{a}}$ & -0.28 & -1.38 & -1.55 & $-1.71^{\mathrm{c}}$ & -0.63 \\
C3o & $-2.96^{\mathrm{a}}$ & $2.52^{\mathrm{b}}$ & $2.85^{\mathrm{a}}$ & $4.65^{\mathrm{a}}$ & $4.60^{\mathrm{a}}$ & $5.50^{\mathrm{a}}$ \\
C5 & $2.70^{\mathrm{a}}$ & -0.14 & -0.61 & -0.15 & 0.22 & 0.66 \\
Herfindahl & $1.88^{\mathrm{c}}$ & 0.10 & -1.25 & -1.43 & -1.27 & -0.24 \\
\hline \hline
\end{tabular}

Panel E: 1960 vs. 1900 (non-survivors only) - Tests of means (t-statistics)

\begin{tabular}{lcccccc}
\hline \hline & 1960 vs. 1900 & 1970 vs. 1910 & 1980 vs. 1920 & 1990 vs. 1930 & 2000 vs. 1940 & Overall \\
\hline Directors & 1.50 & -0.46 & -1.19 & $-1.92^{\mathrm{c}}$ & $-3.28^{\mathrm{a}}$ & $-2.41^{\mathrm{b}}$ \\
C3 & $3.44^{\mathrm{a}}$ & 0.00 & -0.30 & -0.90 & $-1.96^{\mathrm{c}}$ & -0.01 \\
C3i & $3.07^{\mathrm{a}}$ & 0.07 & -1.17 & $-2.01^{\mathrm{c}}$ & $-3.17^{\mathrm{a}}$ & -1.38 \\
C3o & -0.92 & -0.62 & 1.68 & $2.93^{\mathrm{a}}$ & $3.65^{\mathrm{a}}$ & $2.99^{\mathrm{a}}$ \\
C5 & $2.15^{\mathrm{b}}$ & -0.52 & -0.67 & -0.86 & -1.53 & -0.87 \\
Herfindahl & $3.28^{\mathrm{a}}$ & 0.52 & -1.18 & $-1.85^{\mathrm{c}}$ & $-2.88^{\mathrm{a}}$ & -0.88 \\
\hline \hline
\end{tabular}


Table 5 - Factors contributing to changes in directors' shareholdings

This table reports the reduction of directors' shareholdings (computed from Table 4) at 10 yearly intervals in column 1 and the factors contributing to the reduction. Frequency is the number of occurrences of the event in question in the decade and impact is the percentage of the reduction attributable to each factor - IPOs, acquisitions, rights issues, and placings. Panel A refers to the complete 1900 sample, while Panel B considers the 1960 sample.

Panel A: Factors contributing to reduction in directors' shareholdings, complete 1900 sample

\begin{tabular}{|c|c|c|c|c|c|c|c|c|c|}
\hline & \multirow{3}{*}{$\begin{array}{c}\text { Reduction in directors' } \\
\text { shareholdings }(\%)\end{array}$} & \multicolumn{8}{|c|}{ Factors influencing reduction in directors' shareholdings } \\
\hline & & \multicolumn{2}{|c|}{ IPOs } & \multicolumn{2}{|c|}{ Acquisitions } & \multicolumn{2}{|c|}{ Rights issues } & \multicolumn{2}{|c|}{ Placings } \\
\hline & & Freq. & Impact & Freq. & Impact & Freq. & Impact & Freq. & Impact \\
\hline $1900-1910$ & 39.15 & 0 & 0.00 & 25 & 39.06 & 17 & 0.52 & 10 & 28.02 \\
\hline $1910-1920$ & 4.59 & 0 & 0.00 & 5 & 77.97 & 9 & 0.00 & 1 & 2.34 \\
\hline $1920-1930$ & 11.60 & 0 & 0.00 & 7 & 25.95 & 9 & 0.00 & 2 & 3.37 \\
\hline $1930-1940$ & -0.27 & 3 & 0.00 & 3 & 0.00 & 11 & 0.00 & 0 & 0.00 \\
\hline $1940-1950$ & 10.09 & 6 & 0.24 & 1 & 0.00 & 4 & 1.24 & 0 & 0.00 \\
\hline $1950-1960$ & -2.25 & 4 & 0.00 & 10 & 0.00 & 15 & 0.00 & 0 & 0.00 \\
\hline $1960-1970$ & 8.45 & 4 & 31.99 & 24 & 11.16 & 8 & 13.09 & 0 & 0.00 \\
\hline $1970-1980$ & 2.87 & 1 & 0.00 & 9 & 3.23 & 19 & 25.51 & 0 & 0.00 \\
\hline $1980-1990$ & 5.30 & 1 & 5.73 & 4 & 19.85 & 14 & 15.23 & 2 & 0.00 \\
\hline $1990-2000$ & 2.78 & 3 & 65.27 & 3 & 2.75 & 14 & 47.01 & 10 & 26.03 \\
\hline Mean & 9.40 & 2.20 & 4.20 & 9.10 & 32.51 & 12.00 & 5.62 & 2.50 & 16.57 \\
\hline
\end{tabular}

Panel B: Factors contributing to reduction in directors' shareholdings, 1960 sample

\begin{tabular}{|c|c|c|c|c|c|c|c|c|c|}
\hline & \multirow{3}{*}{$\begin{array}{c}\text { Reduction in directors' } \\
\text { shareholdings }(\%)\end{array}$} & \multicolumn{8}{|c|}{ Factors influencing reduction in directors' shareholdings } \\
\hline & & \multicolumn{2}{|c|}{ IPOs } & \multicolumn{2}{|c|}{ Acquisitions } & \multicolumn{2}{|c|}{ Rights issues } & \multicolumn{2}{|c|}{ Placings } \\
\hline & & Freq. & Impact & Freq. & Impact & Freq. & Impact & Freq. & Impact \\
\hline $1960-1970$ & 53.04 & 10 & 11.42 & 27 & 54.52 & 17 & 4.61 & 6 & 21.35 \\
\hline $1970-1980$ & 11.69 & 3 & 17.42 & 23 & 6.32 & 6 & 4.97 & 1 & 6.74 \\
\hline $1980-1990$ & 14.78 & 2 & 34.22 & 4 & 12.99 & 10 & 4.85 & 2 & 9.93 \\
\hline $1990-2000$ & 5.55 & 4 & 4.28 & 4 & 12.73 & 4 & 22.49 & 4 & 78.34 \\
\hline Mean & 21.27 & 5.00 & 16.84 & 14.50 & 21.64 & 9.25 & 9.23 & 3.25 & 29.09 \\
\hline
\end{tabular}


Table 6 - Dispersion of ownership

This table reports the annual rates of dispersion of ownership over time. Ownership is defined as the minimum number of shareholders necessary to pass the threshold of $25 \%$ of cash flow rights, as reported in Table 2 . Dispersion is defined as the change in ownership over the decade. The rates of dispersion are computed for all shareholders, directors alone, and outsiders alone using the formula described in the text. Panel A refers to the 1900 sample, Panel B to the 1960 sample and Panel C reports t-statistics of differences in means across the two samples (1960 minus 1900) for the first four decades of each sample. Panels D and E report t-statistics of differences of the 1960 sample with the surviving and non-surviving companies in the 1900 sample, respectively. Superscript letters a, b, c indicate significance at 1, 5 and 10 percent levels, respectively.

Panel A: Annual rates of dispersion of ownership (\%) - complete 1900 sample

\begin{tabular}{lcccc}
\hline \hline & All shareholders & Directors & Outsiders & N. Obs. \\
\hline $1900-1910$ & 5.93 & 21.12 & 36.66 & 40 \\
$1910-1920$ & 3.49 & 12.38 & 11.65 & 38 \\
$1920-1930$ & 4.07 & 14.83 & 4.69 & 37 \\
$1930-1940$ & 0.52 & 15.80 & -6.24 & 33 \\
$1940-1950$ & 3.03 & -2.90 & 8.81 & 31 \\
$1950-1960$ & 1.79 & 4.29 & 1.37 & 25 \\
$1960-1970$ & 0.42 & -7.47 & 10.03 & 23 \\
$1970-1980$ & 0.07 & 8.81 & -0.02 & 22 \\
$1980-1990$ & -5.64 & 13.82 & -6.57 & 22 \\
$1990-2000$ & 0.24 & 5.00 & 3.99 & 20 \\
\hline Mean & 1.97 & 10.29 & 1.22 & \\
\hline \hline
\end{tabular}

Panel B: Annual rates of dispersion of ownership - 1960 sample

\begin{tabular}{lcccc}
\hline \hline & All shareholders & Directors & Outsiders & N. Obs. \\
\hline $1960-1970$ & 12.36 & 36.08 & 70.21 & 20 \\
$1970-1980$ & -1.70 & 6.77 & 11.40 & 20 \\
$1980-1990$ & 6.08 & 31.41 & 10.47 & 20 \\
$1990-2000$ & -2.22 & 14.67 & -1.13 & 20 \\
\hline Mean & 3.63 & 22.23 & 22.74 & \\
\hline \hline
\end{tabular}

Panel C: 1960 vs. 1900 (complete sample) - Tests of means (t-statistics)

\begin{tabular}{lccccc}
\hline & First decade & Second decade & Third decade & Fourth decade & Overall \\
\hline All shareholders & 1.45 & $-1.99^{\mathrm{c}}$ & 0.73 & -1.09 & -0.01 \\
Directors & 1.27 & -0.46 & 1.49 & -0.11 & 1.06 \\
Outsiders & $2.48^{\mathrm{b}}$ & -0.03 & 0.62 & 1.14 & $1.72^{\mathrm{c}}$ \\
\hline \hline
\end{tabular}

Panel D: 1960 vs. 1900 (survivors only) - Tests of means (t-statistics)

\begin{tabular}{lccccc}
\hline & First decade & Second decade & Third decade & Fourth decade & Overall \\
\hline All shareholders & 0.55 & -1.67 & 0.38 & -1.49 & -0.39 \\
Directors & 1.06 & 0.01 & 0.78 & -0.43 & 0.77 \\
Outsiders & $4.79^{\mathrm{a}}$ & 0.08 & -0.38 & 1.02 & $2.59^{\mathrm{b}}$ \\
\hline \hline
\end{tabular}

Panel E: 1960 vs. 1900 (non-survivors only) - Tests of means (t-statistics)

\begin{tabular}{lccccc} 
& First decade & Second decade & Third decade & Fourth decade & Overall \\
\hline All shareholders & $1.79^{\mathrm{c}}$ & $-1.93^{\mathrm{c}}$ & 1.25 & -0.10 & 0.46 \\
Directors & 1.06 & -0.72 & $1.79^{\mathrm{c}}$ & 0.47 & 0.99 \\
Outsiders & 0.32 & -0.14 & $1.81^{\mathrm{c}}$ & 1.30 & 0.39 \\
\hline \hline
\end{tabular}


Table 7 - Mutation of ownership

This table reports the annual rates of mutation of ownership over time. The ruling coalition is defined as the set of shareholders necessary to pass the threshold of $25 \%$ of cash flow rights, as reported in Table 2. Mutation is defined as the change in the composition of ownership or turnover of the ruling coalition. The rates of mutation are computed for all shareholders, for directors alone (both in terms of cash flows rights and of simple board majority), and for outsiders, respectively, using the formula described in the text. Panel A refers to the 1900 sample, Panel B to the 1960 sample and Panel C reports t-statistics of differences in means across the two samples (1960 minus 1900) for the first four decades of each sample. Superscript letters a, b, c indicate significance at 1,5 and 10 percent levels, respectively.

Panel A: Annual rates of mutation of ownership - 1900 sample

\begin{tabular}{lcrcc}
\hline \hline & All shareholders & Directors & Outsiders & N. Obs. \\
\hline $1900-1910$ & 3.25 & 3.33 & 41.97 & 40 \\
$1910-1920$ & 10.45 & 7.10 & 20.15 & 38 \\
$1920-1930$ & 16.79 & 13.19 & 23.27 & 37 \\
$1930-1940$ & 20.67 & 19.75 & 22.92 & 33 \\
$1940-1950$ & 25.03 & 26.78 & 21.01 & 31 \\
$1950-1960$ & 23.56 & 7.78 & 24.24 & 25 \\
$1960-1970$ & 21.86 & 23.17 & 40.57 & 23 \\
$1970-1980$ & 33.97 & 26.56 & 24.13 & 22 \\
$1980-1990$ & 55.03 & 26.84 & 60.04 & 22 \\
$1990-2000$ & 42.03 & 30.74 & 42.09 & 20 \\
\hline Mean & 26.52 & 21.45 & 37.92 & \\
\hline \hline
\end{tabular}

Panel B: Annual rates of mutation of ownership - 1960 sample

\begin{tabular}{lcccc}
\hline \hline & All shareholders & Directors & Outsiders & N. Obs. \\
\hline $1960-1970$ & 16.19 & 21.19 & 65.00 & 20 \\
$1970-1980$ & 33.12 & 32.60 & 55.24 & 20 \\
$1980-1990$ & 57.81 & 52.43 & 70.33 & 20 \\
$1990-2000$ & 52.94 & 43.45 & 55.86 & 20 \\
\hline Mean & 40.10 & 37.48 & 61.69 & \\
\hline \hline
\end{tabular}

Panel C: 1960 vs. 1900 (complete sample) - Tests of means (t-statistics)

\begin{tabular}{lccccc}
\hline \hline & First decade & Second decade & Third decade & Fourth decade & Overall \\
\hline All shareholders & $1.93^{\mathrm{b}}$ & $2.29^{\mathrm{b}}$ & $3.70^{\mathrm{a}}$ & $2.64^{\mathrm{b}}$ & $5.35^{\mathrm{a}}$ \\
Directors & $2.45^{\mathrm{b}}$ & $2.74^{\mathrm{a}}$ & $3.65^{\mathrm{a}}$ & $1.95^{\mathrm{c}}$ & $5.39^{\mathrm{a}}$ \\
Outsiders & $1.74^{\mathrm{c}}$ & $3.06^{\mathrm{a}}$ & $4.22^{\mathrm{a}}$ & $2.79^{\mathrm{a}}$ & $5.66^{\mathrm{a}}$ \\
Directors (board) & $2.88^{\mathrm{a}}$ & $2.23^{\mathrm{b}}$ & $1.71^{\mathrm{c}}$ & 0.71 & $3.77^{\mathrm{a}}$ \\
\hline \hline
\end{tabular}

Panel D: 1960 vs. 1900 (survivors only) - Tests of means (t-statistics)

\begin{tabular}{lccccc}
\hline \hline & First decade & Second decade & Third decade & Fourth decade & Overall \\
\hline All shareholders & 1.06 & 1.60 & $2.40^{\mathrm{b}}$ & $2.14^{\mathrm{b}}$ & $3.60^{\mathrm{a}}$ \\
Directors & $2.26^{\mathrm{b}}$ & 1.61 & $2.55^{\mathrm{b}}$ & 1.22 & $3.65^{\mathrm{a}}$ \\
Outsiders & $2.95^{\mathrm{a}}$ & $2.15^{\mathrm{b}}$ & $3.04^{\mathrm{a}}$ & $1.83^{\mathrm{c}}$ & $5.05^{\mathrm{a}}$ \\
Directors (board) & $2.54^{\mathrm{b}}$ & 1.22 & $1.41^{\mathrm{c}}$ & 0.53 & $2.82^{\mathrm{a}}$ \\
\hline \hline
\end{tabular}

Panel E: 1960 vs. 1900 (non-survivors only) - Tests of means (t-statistics)

\begin{tabular}{lccccc}
\hline \hline & First decade & Second decade & Third decade & Fourth decade & Overall \\
\hline All shareholders & $1.95^{\mathrm{c}}$ & $2.03^{\mathrm{b}}$ & $3.81^{\mathrm{a}}$ & $2.17^{\mathrm{b}}$ & $5.11^{\mathrm{a}}$ \\
Directors & 1.47 & $2.74^{\mathrm{a}}$ & $3.33^{\mathrm{a}}$ & $2.21^{\mathrm{b}}$ & $5.05^{\mathrm{a}}$ \\
Outsiders & 0.29 & $2.92^{\mathrm{a}}$ & $4.26^{\mathrm{a}}$ & $3.06^{\mathrm{a}}$ & $4.48^{\mathrm{a}}$ \\
Directors (board) & $1.79^{\mathrm{c}}$ & $2.39^{\mathrm{b}}$ & 1.25 & 0.65 & $3.09^{\mathrm{a}}$ \\
\hline \hline
\end{tabular}




\section{Table 8 - Determinants of dispersion of ownership}

The dependent variable is the annual rate of dispersion of ownership by decade for the first four decades of the two samples. Independent variables are anti-director rights, the anti-director rights score described in Panel A of Table 1; Disclosure Standards, the disclosure score described in Panel B of Table 1; Liability Standards the directors' liability score described in Panel C of Table 1; Public Enforcement, the public enforcement score described in Panel D of Table 1; equity growth rate for stock acquisitions and equity growth rate for internal investment; size, the log of the sum of all liabilities; and initial dispersion, the size of the smallest coalition necessary to pass the $25 \%$ ownership threshold at the beginning of the decade in question. All regressions include industry and decade dummies. The standard errors reported in parenthesis are adjusted for heteroskedasticity using White's (1980) correction. Superscript letters a, b, c indicate significance at 1, 5 and 10 percent levels, respectively.

\section{(1)}

$-0.010$

Anti director rights

$(.007)$

Disclosure Standards

(.032)

Liability Standards

$(2)$

(3)

4)

Public Enforcement

Equity growth rate from stock acquisitions

Equity growth rate used for internal investment

Size

Initial dispersion

Constant

$\mathrm{R}^{2}$

$\mathrm{N}$ observations
$-0.061$

(.039)

$-0.135^{\mathrm{a}}$

(.035)

$0.084^{\mathrm{b}}$

(.036)

(.036)

$0.088^{\mathrm{b}}$

(.036)

$-0.030$

(.022)

(.022)

$0.012^{\mathrm{b}}$

$0.010^{\mathrm{b}}$

(.005)

(.005)

$0.010^{\mathrm{b}}$

(.005)

$-0.095^{\mathrm{a}}$

(.033)

(.034)

$-0.088^{\mathrm{a}}$

$-0.088^{\mathrm{a}}$

(.034)

$-0.100$

$-0.077$

$-0.087$

$-0.087$

(.077)

(.075)

(.075)
0.245

0.213

223

223 


\section{Table 9 - Determinants of mutation of ownership}

The dependent variable is the annual rate of mutation of ownership by decade for the first four decades of the two samples. Independent variables are anti-director rights, the anti-director rights score described in Panel A of Table 1; Disclosure Standards, the disclosure score described in Panel B of Table 1; Liability Standards the directors' liability score described in Panel C of Table 1; Public Enforcement, the public enforcement score described in Panel D of Table 1; equity growth rate for stock acquisitions and equity growth rate for internal investment; size, the log of the sum of all liabilities; and initial dispersion, the size of the smallest coalition necessary to pass the $25 \%$ ownership threshold at the beginning of the decade in question. All regressions include industry and decade dummies (not reported). The standard errors reported in parenthesis are adjusted for heteroskedasticity using White's (1980) correction. Superscript letters a, b, c indicate significance at 1,5 and 10 percent levels, respectively.

\begin{tabular}{|c|c|c|c|c|}
\hline & $(1)$ & $(2)$ & (3) & (4) \\
\hline Anti director rights & $\begin{array}{l}0.126^{\mathrm{a}} \\
(.042)\end{array}$ & & & \\
\hline Disclosure Standards & & $\begin{array}{l}0.604^{\mathrm{a}} \\
(.105)\end{array}$ & & \\
\hline Liability Standards & & & $\begin{array}{l}0.754^{\mathrm{a}} \\
(.131)\end{array}$ & \\
\hline Public Enforcement & & & & $\begin{array}{l}0.379^{b} \\
(.166)\end{array}$ \\
\hline Equity growth rate from stock acquisitions & $\begin{array}{l}0.082 \\
(.049)\end{array}$ & $\begin{array}{l}0.082 \\
(.049)\end{array}$ & $\begin{array}{l}0.082 \\
(.049)\end{array}$ & $\begin{array}{l}0.010 \\
(.054)\end{array}$ \\
\hline Equity growth rate used for internal investment & $\begin{array}{l}0.257^{\mathrm{b}} \\
(.101)\end{array}$ & $\begin{array}{l}0.257^{\mathrm{b}} \\
(.101)\end{array}$ & $\begin{array}{l}0.257^{\mathrm{b}} \\
(.101)\end{array}$ & $\begin{array}{l}0.204^{\mathrm{c}} \\
(.116)\end{array}$ \\
\hline Size & $\begin{array}{c}-0.012 \\
(.010)\end{array}$ & $\begin{array}{c}-0.012 \\
(.010)\end{array}$ & $\begin{array}{c}-0.012 \\
(.010)\end{array}$ & $\begin{array}{r}-0.002 \\
(.010)\end{array}$ \\
\hline Initial dispersion & $\begin{array}{l}0.263^{\mathrm{a}} \\
(.069)\end{array}$ & $\begin{array}{l}0.263^{\mathrm{a}} \\
(.069)\end{array}$ & $\begin{array}{l}0.263^{\mathrm{a}} \\
(.069)\end{array}$ & $\begin{array}{l}0.281^{\mathrm{a}} \\
(.072)\end{array}$ \\
\hline Constant & $\begin{array}{l}0.151 \\
(.144)\end{array}$ & $\begin{array}{l}0.277^{\mathrm{c}} \\
(.144)\end{array}$ & $\begin{array}{l}0.277^{\mathrm{c}} \\
(.144)\end{array}$ & $\begin{array}{l}0.385^{\mathrm{b}} \\
(.156)\end{array}$ \\
\hline$\overline{\mathrm{R}^{2}}$ & 0.263 & 0.263 & 0.263 & 0.182 \\
\hline $\mathrm{N}$ observations & 223 & 223 & 223 & 223 \\
\hline
\end{tabular}




\section{Table 10 - Geographic concentration of ownership and mergers}

Panel A provides descriptive statistics of distance in miles between shareholders' addresses and the company's city of incorporation of both ordinary shareholders and preference shareholders in 1910. The third column tests the significance of the difference between the two. Panel B reports probit regressions of the probability that the chairman of the target company joins the board of directors of the acquiring firm after the merger, and tobit regressions of the proportion of directors of the target company that are retained on the board after the merger. For the probit regressions, the reported coefficients are estimates of the effect of a marginal change in the corresponding regressor on the probability of survival of the chairman of the target board, computed at the average of the dependent variable. Distance is one plus the log of the distance in miles between the city of incorporation of the acquiring and target firms. Equity share is the book value of the ordinary shares issued in the acquisition, scaled by the total value of the deal. Bid premium is the one-month returns, unadjusted for a market index, around the announcement of the merger (define more carefully). Relative size is the ratio of the book value of ordinary equity of the target and acquiring firms. The standard errors reported in parenthesis are adjusted for heteroskedasticity using White's (1980) correction. Superscript letters a, b, c indicate significance at 1,5 and 10 percent levels, respectively.

Panel A - Distance of shareholders from company headquarters

\begin{tabular}{|c|c|c|c|c|}
\hline Variable & Description & Ordinary & Preference & $\begin{array}{l}\text { Difference } \\
\text { (z-test) }\end{array}$ \\
\hline $\mathrm{AD}$ & $\begin{array}{l}\text { Average distance (miles) of shareholders from companies' } \\
\text { headquarters }\end{array}$ & 52.20 & 84.33 & $3.39^{* * *}$ \\
\hline WAD & $\begin{array}{l}\text { Average weighted distance (miles) of shareholders from } \\
\text { companies' headquarters }\end{array}$ & 53.62 & 77.89 & $2.05^{* *}$ \\
\hline MD & $\begin{array}{l}\text { Median distance (miles) of shareholders from companies' } \\
\text { headquarters }\end{array}$ & 15.44 & 29.69 & $2.06^{* *}$ \\
\hline MDL & Median distance, 10 largest shareholders & 26.57 & 44.71 & 0.39 \\
\hline Locality & $\begin{array}{l}\text { Percentage of shareholders living within } 6 \text { miles from the } \\
\text { companies' headquarters }\end{array}$ & 56.16 & & \\
\hline NOS & Number of shareholders & 319.35 & 498.31 & $2.10^{* *}$ \\
\hline No. Obs. & & 26 & 16 & 16 \\
\hline
\end{tabular}

Panel B - Determinants of target chairman and target directors' survivorship

\begin{tabular}{|c|c|c|c|c|}
\hline \multirow[t]{2}{*}{ Dependent variable: } & \multicolumn{2}{|c|}{ Probability of target chairman surviving } & \multicolumn{2}{|c|}{ Proportion of target directors surviving } \\
\hline & $(1)$ & $(2)$ & (3) & $(4)$ \\
\hline Distance & $\begin{array}{l}0.401^{c} \\
(.237)\end{array}$ & $\begin{array}{c}0.768^{\mathrm{b}} \\
(.352)\end{array}$ & & $\begin{array}{l}0.118 \\
(.083)\end{array}$ \\
\hline Equity Share & & $\begin{array}{c}2.23^{\mathrm{a}} \\
(.734)\end{array}$ & $\begin{array}{l}0.524^{\mathrm{b}} \\
(.238)\end{array}$ & $\begin{array}{c}0.663^{\mathrm{b}} \\
(.246)\end{array}$ \\
\hline Bid Premium & & $\begin{array}{r}3.81 \\
(2.62)\end{array}$ & & $\begin{array}{r}-0.310 \\
(.743)\end{array}$ \\
\hline Relative Size (Target/Bidder) & & $\begin{array}{c}0.764^{\mathrm{b}} \\
(.381)\end{array}$ & & $\begin{array}{c}0.002 \\
(.003)\end{array}$ \\
\hline Constant & $\begin{array}{r}-0.262 \\
(.377)\end{array}$ & $\begin{array}{c}-2.95^{\mathrm{a}} \\
(1.01)\end{array}$ & $\begin{array}{l}0.475^{\mathrm{b}} \\
(.191)\end{array}$ & $\begin{array}{r}0.287 \\
(.240)\end{array}$ \\
\hline Industry Dummies? & No & Yes & No & Yes \\
\hline Pseudo $\mathrm{R}^{2}$ & 0.089 & 0.356 & 0.130 & 0.230 \\
\hline$\chi^{2}$ & 2.860 & 12.600 & 4.640 & 8.230 \\
\hline No observations & 27 & 23 & 23 & 23 \\
\hline
\end{tabular}


Table A1 - Sample description

The table lists the companies in our sample, their cities of incorporation, incorporation date, IPO date, the earliest years for which we have evidence of the ordinary shares being traded at the London Stock Exchange and/or Provincial Exchanges, and their status (alive, liquidated or taken over) as of 2001. Panel A refers to the 1900 sample and Panel B to the 1960 sample.

Panel A: Incorporated between 1897 and 1903

\begin{tabular}{|c|c|c|c|c|c|c|}
\hline Company Name & City of Inc. & Inc. date & IPO date & Traded (LSE) & Traded (provincial) & Status \\
\hline Albert E. Reed and Co. & London & $28 / 05 / 1903$ & $21 / 04 / 1948$ & 1930 & - & Alive \\
\hline Balkis & London & $14 / 12 / 1898$ & - & 1899 & - & Liq. 1954 \\
\hline Bleachers Association & Manchester & 07/06/1900 & $1927-1930$ & 1907 & 1900 (Manchester, et al) & Liq. 1997 \\
\hline Broomhill Collieries & Newcastle on Tyne & $01 / 11 / 1900$ & - & - & 1903 (Newcastle) & Liq. 1955 \\
\hline Cadbury Brothers & Birmingham & $13 / 06 / 1899$ & - & 1968 & 1961 (Birmingham) & T.O. 1969 \\
\hline $\mathrm{C}$ and $\mathrm{W}$ Walker Ltd & Donnington, Newport & $03 / 05 / 1899$ & $17 / 08 / 1998$ & 1899 & 1899 (Birmingham) & Alive \\
\hline Chamberlin and Hill & Walsall & 03/04/1903 & $25 / 03 / 1973$ & 1973 & 1956 (Birmingham) & Alive \\
\hline Charles Cammell and Co. & Sheffield & 04/01/1898 & 23/06/1949 & 1904 & 1905 (Sheffield et al) & Alive \\
\hline Dickson and Benson & Middlesbrough & 06/03/1900 & - & 1920 & - & Liq. 1964 \\
\hline General Electric Co. & London & $27 / 09 / 1900$ & $30 / 11 / 1999$ & 1919 & 1921 (Birm., Manch.) & Alive \\
\hline Gillard and Co. & Walthamstow, London & $26 / 07 / 1898$ & - & - & - & Liq. 1977 \\
\hline Guest, Keen, and Co., Ltd & Birmingham & 09/07/1900 & $14 / 06 / 1946$ & 1900 & 1900 (Birmingham) & Alive \\
\hline Henry Tate and Sons & London & $27 / 02 / 1903$ & $09 / 12 / 1938$ & 1929 & 1928 (Liverpool) & Alive \\
\hline Higgs and Hill & New Malden, Surrey & $07 / 02 / 1898$ & $11 / 07 / 1960$ & 1960 & - & Alive \\
\hline Horace Cory, Ltd & London & $18 / 04 / 1900$ & $05 / 08 / 1956$ & 1900 & - & Alive \\
\hline Johnson Brothers (Dyers) & Dewsbury, Yorkshire & $08 / 12 / 1898$ & - & 1937 & - & Liq. 1957 \\
\hline John Williams and Sons & Cardiff, Wales & 28/11/1899 & Around 1950 & 1950 & 1950 (Midlands\&West) & Liq. \\
\hline Klanang Produce & London & 01/05/1899 & - & 1923 & - & Liq. 1961 \\
\hline Leeds and District Worsted Dyers & Leeds & $21 / 11 / 1900$ & $24 / 08 / 1965$ & 1965 & 1921 (Leeds) & Alive \\
\hline Manganese Bronze and Brass Co. & London & $10 / 03 / 1899$ & $24 / 04 / 1940$ & 1899 & 1920 (Leeds, Manch.) & Alive \\
\hline Midland Rubber & Birmingham & 1900 & - & - & 1901 (Birmingham) & Liq. 1912 \\
\hline Mining and Industrial Corp. & London & 1900 & - & - & - & Liq. 1912 \\
\hline New Hucknall Collieries & Huthwark, Notthingham & $28 / 12 / 1900$ & - & - & 1930 (Notthingham, Sheff.) & Liq. 1957 \\
\hline Ocean Steam Ship Co. & Liverpool & 06/06/1902 & $12 / 03 / 1965$ & 1965 & 1963 (Northern) & Alive \\
\hline Pease and Partners & Darlington, Durham & $11 / 10 / 1898$ & - & 1928 & 1920 (Birm., Bristol, et al.) & Liq. 1958 \\
\hline Queen Mill Dukinfield & Stalybridge & $23 / 07 / 1900$ & - & - & 1938 (Oldham) & Liq. 1963 \\
\hline Reckitt and Sons & Hull & 04/07/1899 & - & 1929 & 1911 (Leeds) & Liq. 1956 \\
\hline Rock Brewery & Brighton & 03/04/1901 & - & - & - & T.O. 1926 \\
\hline Schweppes, Ltd & London & $06 / 05 / 1897$ & $19 / 12 / 1942$ & 1897 & 1897 (Manchester) & Alive \\
\hline South Australian Dredging & London & $19 / 04 / 1902$ & - & - & - & T.O. 1950 \\
\hline South Hetton Coal Co. & Sunderland & 07/05/1898 & - & 1920 & 1899 (Newcastle) & Liq. 1956 \\
\hline Stewart and Wight & London & $29 / 04 / 1898$ & $25 / 03 / 1960$ & 1921 & - & Alive \\
\hline Thomas De La Rue & London & 01/07/1898 & $27 / 07 / 1947$ & 1926 & - & Alive \\
\hline Thomas, Evans \& John Dyer & Swansea, Wales & 03/07/1900 & - & - & 1930 (Cardiff, Swansea) & Liq. 1964 \\
\hline Tilbury Contracting and Dredging & London & $16 / 08 / 1902$ & $12 / 10 / 1966$ & 1928 & - & Alive \\
\hline Tuttle and Sons & London & $22 / 01 / 1902$ & $26 / 04 / 1996$ & 1996 & - & Alive \\
\hline Weardale, Steel Coal \& Coke & West Hartlepool, Durham & 29/09/1899 & - & 1930 & 1926 (Newcastle, Sh., et al) & Liq. 1957 \\
\hline West Bromwich Spring & West Bromwich & $14 / 11 / 1903$ & 06/11/1989 & 1989 & 1967 (Midland\&West) & Alive \\
\hline Yang-Tse Corporation & London & $14 / 09 / 1898$ & $24 / 03 / 1958$ & 1921 & 1898 & Alive \\
\hline Yorkshire Dye ware and Chemical & Huddersfield, Yorkshire & $19 / 05 / 1900$ & 08/09/1947 & 1921 & 1900 (Leeds) & Alive \\
\hline
\end{tabular}

Panel B: Incorporated between 1958 and 1962

\begin{tabular}{|c|c|c|c|c|c|c|}
\hline Company Name & City of Inc. & Inc. date & IPO date & Traded (LSE) & Traded (provincial) & Status \\
\hline Albert Fisher Group & Nelson, Lancashire & $06 / 02 / 1961$ & $21 / 09 / 1973$ & 1973 & 1965 (Liverpool) & Alive \\
\hline Blanes & London & $01 / 05 / 1959$ & $25 / 03 / 1974$ & 1974 & - & Alive \\
\hline Block Holdings, Ltd & London & $15 / 12 / 1959$ & 09/07/1985 & 1985 & - & Alive \\
\hline Central Properties (Kensington) & London & $20 / 06 / 1961$ & $10 / 12 / 1985$ & 1985 & - & Alive \\
\hline Ceylon Tea Plantation Holdings & London & $27 / 09 / 1960$ & $05 / 10 / 1960$ & 1909 & - & Alive \\
\hline Countryside Properties & London & $14 / 11 / 1958$ & $15 / 11 / 1972$ & 1972 & - & Alive \\
\hline Dalkeith (Ceylon) Holdings & Dalkeith & $17 / 11 / 1960$ & 05/01/1999 & 1999 & - & Alive \\
\hline Hill \& Smith Holdings & Brierley Hill, Staffordshire & $30 / 09 / 1960$ & $26 / 03 / 1969$ & 1969 & - & Alive \\
\hline Ind Coope Tetley Ansell & London & $13 / 04 / 1961$ & $13 / 05 / 1961$ & 1961 & 1961 (Birmingham et al) & Alive \\
\hline J H Haynes and Co. & Yeovil, Somerset & $18 / 05 / 1960$ & 07/11/1996 & 1996 & - & Alive \\
\hline Lowland Investment & London & $20 / 09 / 1960$ & $05 / 04 / 1966$ & 1966 & - & Alive \\
\hline Mining Supplies & Doncaster, Yorkshire & $24 / 03 / 1960$ & $24 / 03 / 1965$ & 1965 & - & Alive \\
\hline Nasmo Machinery & Wolverhampton & 02/07/1959 & $11 / 11 / 1968$ & 1968 & 1968 (Midlands \& West) & Alive \\
\hline Oldeani Developments Ltd & Birmingham & $18 / 11 / 1960$ & 29/11/1996 & 1996 & - & Alive \\
\hline Provident Clothing & Bradford, West Yorkshire & $31 / 08 / 1960$ & $16 / 03 / 1962$ & 1962 & - & Alive \\
\hline Rankin Dyson & London & $15 / 12 / 1958$ & $27 / 09 / 2000$ & 2000 & - & Alive \\
\hline Reeve Angel International & London & 23/06/1959 & $17 / 11 / 1960$ & 1960 & - & Alive \\
\hline Rem Products (Electrical) & Leigh-on-Sea, Essex & $14 / 03 / 1961$ & $29 / 02 / 1996$ & 1996 & - & Alive \\
\hline Serapsoidar & London & $22 / 01 / 1960$ & $14 / 06 / 1967$ & 1967 & - & Alive \\
\hline Town Centre Securities & Leeds & 17/03/1959 & $21 / 09 / 1960$ & 1960 & - & Alive \\
\hline
\end{tabular}




\section{Table A2 - The Size of the London Stock Exchange and Provincial Stock Exchanges at the end of 1899}

The table provides the total number of firms, securities traded and market capitalization of the London Stock exchange and provincial stock exchanges at the end of 1899 , broken down by industry. It includes the percentage of securities only quoted in London and those quoted only on provincial exchanges.

\begin{tabular}{|c|c|c|c|c|c|c|c|c|}
\hline \multirow[t]{2}{*}{ Industry } & \multirow[t]{2}{*}{ No of firms } & \multirow[t]{2}{*}{ No of Securities } & \multirow{2}{*}{$\begin{array}{c}\text { Total Mkt. Cap } \\
(\mathrm{GBP})\end{array}$} & \multirow[t]{2}{*}{ Percent Mkt. Cap } & \multicolumn{2}{|c|}{ Quoted Only in London } & \multicolumn{2}{|c|}{ Outside London Only } \\
\hline & & & & & No & Percent & No & Percent \\
\hline Breweries and Distilleries & 149 & 326 & $86,068,140.20$ & 7.79 & 87 & 58.39 & 23 & 15.44 \\
\hline Canals & 13 & 25 & $13,114,302.50$ & 1.19 & 1 & 7.69 & 10 & 76.92 \\
\hline British Corporations and Counties & 107 & 157 & $143,583,879.00$ & 13.00 & 57 & 53.27 & 25 & 23.36 \\
\hline Colonial and Foreign Corporations & 53 & 85 & $187,376,295.00$ & 16.97 & 58 & 109.43 & 0 & 0.00 \\
\hline Docks & 13 & 19 & $7,350,587.00$ & 0.67 & 5 & 38.46 & 8 & 61.54 \\
\hline Gas and Lighting & 58 & 104 & $67,236,800.80$ & 6.09 & 44 & 75.86 & 9 & 15.52 \\
\hline Iron, Coal and Steel & 80 & 126 & $40,279,692.60$ & 3.65 & 10 & 12.50 & 51 & 63.75 \\
\hline Land, Mortgage, Financial & 103 & 168 & $76,325,272.80$ & 6.91 & 55 & 53.40 & 27 & 26.21 \\
\hline Spinning and Weaving & 23 & 24 & $552,446.40$ & 0.05 & 0 & 0.00 & 22 & 95.65 \\
\hline Steamship and Shipbuilding & 43 & 63 & $11,284,660.80$ & 1.02 & 12 & 27.91 & 16 & 37.21 \\
\hline Tea and Coffee & 41 & 65 & $1,919,938.15$ & 0.17 & 24 & 58.54 & 2 & 4.88 \\
\hline Telegraph & 21 & 40 & $37,697,568.00$ & 3.41 & 14 & 66.67 & 0 & 0.00 \\
\hline Tramway and Omnibus & 37 & 57 & $13,687,415.70$ & 1.24 & 15 & 40.54 & 6 & 16.22 \\
\hline Trusts & 52 & 139 & $58,019,725.90$ & 5.25 & 34 & 65.38 & 8 & 15.38 \\
\hline Wagon and Railway Carriage & 13 & 18 & $695,382.30$ & 0.06 & 1 & 7.69 & 12 & 92.31 \\
\hline Waterworks & 23 & 47 & $26,447,459.30$ & 2.39 & 15 & 65.22 & 5 & 21.74 \\
\hline Other Companies & 365 & 639 & $164,564,546.00$ & 14.90 & 154 & 42.19 & 63 & 17.26 \\
\hline Mining Companies - excluding Iron, Ore and Coal & 160 & 156 & $168,164,880.00$ & 15.23 & 45 & 28.13 & 5 & 3.13 \\
\hline Total & 1354 & 2258 & $1,104,368,992.00$ & 100.00 & 631 & 46.60 & 292 & 21.57 \\
\hline
\end{tabular}


Table A3: Chronology of Company Law and Financial Market Regulation

\begin{tabular}{cl}
\hline \hline Year & Rule \\
\hline 1843 & Absolute majority $\left(50^{+}\right)$ \\
1883 & $\begin{array}{l}\text { Proxy voting not permitted } \\
1889\end{array}$ \\
& $\begin{array}{l}\text { Liability standard for } \\
\text { prospectus statements is } \\
\text { intent }\end{array}$ \\
1890 & $\begin{array}{l}\text { Liability standard for } \\
\text { prospectus statements is } \\
\text { negligence }\end{array}$ \\
1900 & $\begin{array}{l}\text { Prospectus filing } \\
\text { Statement in lieu of } \\
\text { prospectus } \\
\text { Recording rule }\end{array}$ \\
1900
\end{tabular}

1921 Non listed companies' rules

Description

Source

Majority of votes prevails in company law.

No common law right on the part of a shareholder to vote by proxy.

Rule in Foss v. Harbottle

Liability standards for directors, distributors and accountants is intent that is, plaintiffs have to prove affirmatively that the statements were made fraudulently.

Liability standards for directors, distributors and accountants is negligence that is, investors must prove that directors acted with negligence and that their losses were caused by the misleading statements.

Required to be filed at Companies House. Must contain specific material.

Shares can be traded without a prospectus (as before), provided the issuer files a statement with the registrar.

All trades to be recorded in Stock Exchange's Official List or Supplementary List. Former is for quoted companies on LSE, and latter is for companies without a quotation but where dealing is allowed.

1929 Prospectus is required, and must contain specific information

Stock exchange published stricter rules covering permission to deal in unquoted companies.

A prospectus is required both by Corporate Law and the London Stock Exchange. In the prospectus, the issuer has to disclose the compensation, inside ownership of each director, as well as contracts made by the issuer outside the course of the business, and all transactions in which related parties have, or will have, an interest.

1929 Liability standard for prospectus statements is reliance

1929 Notice of accounts

1929 Book keeping and filing accounts

1929 New listing rules

1939 Directors' disclosure

1947 New listing rules

1948 Squeeze out rule (90\%)

1948 Proxy voting introduced

1948 Removal of directors

1948 Min votes to force EGM

1948 Penalties for non disclosure

1967 Mandatory bid (30\%)

1967 Supra majority (75\%)

1967 Block disclosure (10\%)

1967 Disclosure of intention to bid

1976 Block disclosure (5\%)

1980 Pre-emption rights

1985 Block disclosure (3\%)

1985 Oppressed minorities

Liability standards for directors, distributors and accountants is reliance that is, investors must only prove that the statement is untrue, and that they relied on such statements.

Balance sheets and P\&L accounts must be sent out at least 7 days before AGM.

Company must keep proper books including a P\&L account and Balance Sheet. Public companies must file a balance sheet with Registrar of Companies.

Followed collapse of 1928 new issue boom, stricter rules introduced for admission to both Lists, including permission to deal.

Disclosure of contracts with directors.

Differences between Official List and Supplementary Lists (see above) are abolished. Conditions for granting an Official Quotation significantly tightened: 10 years profits record required compared with 5 under 1948 Companies Act and support of 2 exchange dealers. Also, if permission to deal is refused all funds raised in the issue must be returned to subscribers, making it impossible to raise money without permission to deal.

Squeeze out rule: $90 \%$ shareholder can buy out minority at original bid price.

Notice of meetings with minimum of 21 days. Allows voting by proxy (Anti director rule).

Made easier by special resolution.

$10 \%$ of shares can force an EGM (Anti director rule).

Disclosure requirements in prospectus and penalties for non disclosure. Detailed provisions regarding the form and content of balance sheets and P\&L accounts. Requirement that company accounts provide a "true and fair" view of a company's financial position.

Compulsory tender offer for remaining shares.

Min. votes required to approve a merger via a scheme of arrangement, and waive pre-emption rights for equity issues to new shareholders.

Holders of blocks of $10 \%$ or more must be disclosed.

Holders of blocks of $15 \%$ or more must express intentions to bid.

Holders of blocks of $5 \%$ or more must be disclosed.

New share issues must be offered to existing shareholders first.

Holders of blocks of $3 \%$ or more must be disclosed.

It allows court review of decisions 'on the grounds that the company's affairs are being or have been conducted in a manner which is unfairly prejudicial to the interests of its members generally or of some part of its members'.

1986 FSA is created Self-Regulatory Organizations (SROs) of the London Stock Exchange are introduced. Later, all Stock Exchange regulation and enforcement was centralized under the Financial Services Authority.

Rule in Harben v. Phillips

Rule in Derry v. Peek

Directors' Liability Act, S 3

Company law

Companies Act, S 1 (confirmed in 1907, S 4)

Companies Act

London Stock Exchange

Companies Act, S 35

Companies Act, S 37

London Stock Exchange

Companies Act, S 122124.

London Stock Exchange

Company law

London Stock Exchange

Companies Act, S 209

Companies Act, [S 136]

Companies Act, S 184

Company law, S 132

Companies Act, S 38 \&

Fourth Schedule

Takeover Code

Company law

Companies Act, S 33 .

City Code on Takeover \& Mergers

Companies Act, S 26.

Companies Act, S 17

Companies Act, S 198.9

Companies Act, S 459

Financial Services Act 


\section{Table A4 - Definitions of various indices of investor protection and enforcement}

This table reports the evolution of various indices of investor protection and enforcement. Panel A reports the evolution over time of the anti-director index over time, as defined by La Porta, Lopez-de-Silanes, Shleifer and Vishny (1998, p. 1123): "An index aggregating the shareholder rights which we labeled as 'anti-director rights.' The index is formed by adding 1 when: (1) the country allows shareholders to mail their proxy vote to the firm; (2) shareholders are not required to deposit their shares prior to the General Shareholders' Meeting; (3) cumulative voting or proportional representation of minorities in the board of directors is allowed; (4) an oppressed minorities mechanism is in place; (5) the minimum percentage of share capital that entitles a shareholder to call for an Extraordinary Shareholders' Meeting is less than or equal to 10 percent (the sample median); or (6) shareholders have preemptive rights that can only be waived by a shareholders' vote. The index ranges from 0 to 6."

Panel B reports the evolution over time of two indices of private enforcement, disclosure requirements and liability standards, as defined by La Porta, Lopez-de-Silanes, and Shleifer (2004), and Panel C reports the evolution over time of the public enforcement index, as defined by La Porta, Lopez-de-Silanes, and Shleifer (2004).

\section{Panel A - Description of the anti-director rights index}

\begin{tabular}{|c|c|c|}
\hline Shareholder Right & Description & Year of introduction \\
\hline Proxy by mail allowed & $\begin{array}{l}\text { Equals one if the Company Law or Commercial Code allows } \\
\text { shareholders to mail their proxy vote to the firm, and zero } \\
\text { otherwise. }\end{array}$ & 1948 Companies Act (S. 136) \\
\hline Shares not blocked before meeting & $\begin{array}{l}\text { Equals one if the Company Law or Commercial Code does not } \\
\text { allow firms to require that shareholders deposit their shares } \\
\text { prior to a General Shareholders Meeting thus preventing them } \\
\text { from selling those shares for a number of days, and zero } \\
\text { otherwise. }\end{array}$ & Always been in place. \\
\hline $\begin{array}{l}\text { Cumulative voting or proportional } \\
\text { representation }\end{array}$ & $\begin{array}{l}\text { Equals one if the Company Law or Commercial Code allows } \\
\text { shareholders to cast all of their votes for one candidate } \\
\text { standing for election to the board of directors (cumulative } \\
\text { voting) or if the Company Law or Commercial Code allows a } \\
\text { mechanism of proportional representation in the board by } \\
\text { which minority interests may name a proportional number of } \\
\text { directors to the board, and zero otherwise. }\end{array}$ & Never been in place. \\
\hline Oppressed minorities mechanism & $\begin{array}{l}\text { Equals one if the Company Law or Commercial Code grants } \\
\text { minority shareholders either a judicial venue to challenge the } \\
\text { decisions of management or of the assembly or the right to step } \\
\text { out of the company by requiring the company to purchase their } \\
\text { shares when they object to certain fundamental changes, such } \\
\text { as mergers, assets dispositions and changes in the articles of } \\
\text { incorporation. The variable equals zero otherwise. Minority } \\
\text { shareholders are defined as those shareholders who own } 10 \\
\text { percent of share capital or less. }\end{array}$ & $\begin{array}{l}\text { Section } 459 \text { of } 1985 \text { Companies Act which } \\
\text { allows court review of decisions 'on the grounds } \\
\text { that the company's affairs are being or have been } \\
\text { conducted in a manner which is unfairly } \\
\text { prejudicial to the interests of its members } \\
\text { generally or of some part of its members'. }\end{array}$ \\
\hline $\begin{array}{l}\text { Percentage of share capital to call } \\
\text { an extraordinary shareholders } \\
\text { meeting }\end{array}$ & $\begin{array}{l}\text { It is the minimum percentage of ownership of share capital that } \\
\text { entitles a shareholder to call for an Extraordinary } \\
\text { Shareholders' Meeting. }\end{array}$ & $\begin{array}{l}1948 \text { Companies Act (Section 132) } 10 \% \text { of } \\
\text { shares can force an EGM. }\end{array}$ \\
\hline Preemptive Rights to new issues & $\begin{array}{l}\text { Equals one when the Company Law or Commercial Code } \\
\text { grants shareholders the first opportunity to buy new issues of } \\
\text { stock and this right can only be waved by a shareholders' vote, } \\
\text { and zero otherwise. }\end{array}$ & $\begin{array}{l}1980 \text { Companies Act (Section 17) provides that } \\
\text { new share issues must be offered to existing } \\
\text { shareholders or a vote taken each and every time } \\
\text { to suspend the provision. }\end{array}$ \\
\hline
\end{tabular}


Variable

\section{Panel B.1 Disclosure Requirements Index}

(1) Prospectus Equals one if the law prohibits selling securities that are going to be listed on the largest stock

(2)

Compensation

(3)

Shareholders

(4) Inside

Ownership

(5) Irregular

Contracts

(6)

Transactions

$\underline{\text { Disclosure }}$

exchange of the country without delivering a prospectus to potential investors; equals zero otherwise. An index of prospectus disclosure requirements regarding the compensation of directors and key officers. Equals one if the law or the listing rules require that the compensation of each director and key officer be reported in the prospectus of a newly-listed firm; equals one-half if only the aggregate compensation of directors and key officers must be reported in the prospectus of a newly-listed firm; equals zero when there is no requirement to disclose the compensation of directors and key officers in the prospectus for a newly-listed firm.

An index of disclosure requirements regarding the Issuer's equity ownership structure. Equals one if the law or the listing rules require disclosing the name and ownership stake of each shareholder who, directly or indirectly, controls ten percent or more of the Issuer's voting securities; equals one-half if reporting requirements for the Issuer's 10\% shareholders do not include indirect ownership or if only their aggregate ownership needs to be disclosed; equals zero when the law does not require disclosing the name and ownership stake of the Issuer's $10 \%$ shareholders. No distinction is drawn between large-shareholder reporting requirements imposed on firms and those imposed on large shareholders themselves.

An index of prospectus disclosure requirements regarding the equity ownership of the Issuer's shares by its directors and key officers. Equals one if the law or the listing rules require that the ownership of the Issuer's shares by each of its director and key officers be disclosed in the prospectus; equals onehalf if only the aggregate number of the Issuer's shares owned by its directors and key officers must be disclosed in the prospectus; equals zero when the ownership of Issuer's shares by its directors and key officers need not be disclosed in the prospectus.

An index of prospectus disclosure requirements regarding the Issuer's contracts outside the ordinary course of business. Equals one if the law or the listing rules require that the terms of material contracts made by the Issuer outside the ordinary course of its business be disclosed in the prospectus; equals one-half if the terms of only some material contracts made outside the ordinary course of business must be disclosed; equals zero otherwise.

$\mathrm{An}$ index of the prospectus disclosure requirements regarding transaction between the Issuer and its directors, officers, and/or large shareholders (i.e., "related parties"). Equals one if the law or the listing rules require that all transactions in which related parties have, or will have, an interest be disclosed in the prospectus; equals one-half if only some transactions between the Issuer and related parties must be disclosed in the prospectus; equals zero if transactions between the Issuer and related parties need not be disclosed in the prospectus.

The index of disclosure equals the arithmetic mean of: (1) Prospect; (2) Compensation; (3) Shareholders; (4) Inside ownership; (5) Contracts Irregular; (6) and Transactions.

$\begin{array}{llc}0 & 0 & \text { Never } \\ 1 & 0 & 1929\end{array}$

1

0

1967

\section{Panel B.2 Liability Standard Index}

\section{(1) Liability} standard for the issuer and its directors

(2) Liability standard for distributors

(3) Liability standard for accountants

\section{Liability standard index}

\begin{abstract}
Index of the procedural difficulty in recovering losses from the Issuer's directors in a civil liability case for losses due to misleading statements in the prospectus. Equals one when investors are only required to prove that the prospectus contains a misleading statement. Equals two-thirds when investors must also prove that they relied on the prospectus and/or that their loss was caused by the misleading statement. Equals one-third when investors prove that the director acted with negligence and that they either relied on the prospectus or that their loss was caused by the misleading statement or both. Equals zero if restitution from directors is unavailable or the liability standard is intent or gross negligence.

Index of the procedural difficulty in recovering losses from the Distributor in a civil liability case for losses due to misleading statements in the prospectus. Equals one when investors are only required to prove that the prospectus contains a misleading statement. Equals two-thirds when investors must also prove that they relied on the prospectus and/or that their loss was caused by the misleading statement. Equals one-third when investors prove that the Distributor acted with negligence and that they either relied on the prospectus or that their loss was caused by the misleading statement or both. Equals zero if restitution from the Distributor is unavailable or the liability standard is intent or gross negligence. Index of the procedural difficulty in recovering losses from the Accountant in a civil liability case for losses due to misleading statements in the audited financial information accompanying the prospectus. Equals one when investors are only required to prove that the audited financial information accompanying the prospectus contains a misleading statement. Equals two-thirds when investors must also prove that they relied on the prospectus and/or that their loss was caused by the misleading accounting information. Equals one-third when investors prove that the Accountant acted with negligence and that they either relied on the prospectus or that their loss was caused by the misleading statement or both. Equals zero if restitution from the Accountant is unavailable or the liability standard
\end{abstract} is intent or gross negligence.

The index of liability standard equals the arithmetic mean of: (1) for distributors; and (3) Liability standard for accountants. 
Variable

\subsection{Characteristics of the Supervisor of Securities Markets}

(1) Appointment Equals one if a majority of the members of the Supervisor are unilaterally appointed by the Executive branch of

government; equals zero otherwise.

(2) Tenure

(3) Focus

(4) Rules otherwise.

Equals one if separate government agencies or official authorities are in charge of supervising commercial banks and stock exchanges; equals zero otherwise.

Equals one if the Supervisor can generally issue regulations regarding primary offerings and/or listing rules on stock exchanges without prior approval of other governmental authorities. Equals one-half if the Supervisor can generally issue regulations regarding primary offerings and/or listing rules on stock exchanges only with the prior approval of other governmental authorities. Equals zero otherwise.

Supervisor Index The index of characteristics of the Supervisor equals the arithmetic mean of: (1) Appointment; (2) Tenure; (3) Focus; and (4) Rules.

\subsection{Investigative Powers of the Supervisor of Securities Markets}

An index of the power of the Supervisor to comand documents when investigating a violation of securities laws Equals one if the Supervisor can generally issue an administrative order commanding all persons to turn over traded corporations and/or their directors to turn over documents; equals zero otherwise.

(2) Witness An index of the power of the Supervisor to subpoena the testimony of witnesses when investigating a violation of securities laws. Equals one if the Supervisor can generally subpoena all persons to give testimony; equals one-half if the Supervisor can generally subpoena the directors of publicly-traded corporations to give testimony; equals zero otherwise.

Investigative $\quad$ The index of investigative powers equals the arithmetic mean of: (1) Documents; Powers Index $\quad$ and (2) Witness.

\subsection{Sanctions}

(1) Orders issuer An index aggregating stop and do orders that may be directed at the Issuer in case of a defective prospectus. The index is formed by averaging the sub-indexes of orders to stop and to do. The sub-index of orders to stop equals one if the Issuer may be ordered to refrain from a broad range of actions; equals one-half if the Issuer may only be ordered to desist from limited actions; equals zero otherwise. The sub-index of orders to do equals one if the Issuer may be ordered to perform a broad range of actions to rectify the violation; equals one-half if the Issuer may only be ordered to perform limited actions; equals zero otherwise. We disregard orders that may be issued by Courts at the request of a private party in a civil lawsuit.

(2) Order An index aggregating stop and do orders that may be directed at the Distributor in case of a defective prospectus. The index is formed by averaging the sub-indexes of orders to stop and to do. The sub-index of orders to stop equals one if the Distributor may be ordered to refrain from a broad range of actions; equals one-half if the Distributor may only be ordered to desist from limited actions; equals zero otherwise. The sub-index of orders to do equals one if the Distributor may be ordered to perform a broad range of actions to rectify the violation; equals one-half if the Distributor may only be ordered to perform limited actions; equals zero otherwise. We disregard orders that may be issued by Courts at the request of a private party in a civil lawsuit.

An index aggregating stop and do orders that may be directed at the Accountant in case of a defective prospectus. The index is formed by averaging the sub-indexes of orders to stop and to do. The sub-index of orders to stop equals one if the Accountant may be ordered to refrain from a broad range of actions; equals one-half if the Accountant may only be ordered to desist from limited actions; equals zero otherwise. The sub-index of orders to do equals one if the Accountant may be ordered to perform a broad range of actions to rectify the violation; equals one-half if the Accountant may only be ordered to perform limited actions; equals zero otherwise. We disregard orders that may be issued by Courts at the request of a private party in a civil lawsuit.

Orders Index $\quad$ The index of orders equals the arithmetic mean of: (1) Orders issuer; (2) Orders distributor; and (3) Orders accountant.

(1) Criminal An index of criminal sanctions applicable to the Issuer's directors and key officers when the prospectus omits director/officer material information. We create separate sub-indexes for directors and key officers and average their scores. The sub-index for directors equals zero when directors cannot be held criminally liable when the prospectus is misleading. Equals one-half if directors can be held criminally liable when aware that the prospectus is misleading. Equals one if directors can also be held criminally liable when negligently unaware that the prospectus is misleading. The sub-index for key officers is constructed analogously.

(2) Criminal distributor

An index of criminal sanctions applicable to the Distributor (or its officers) when the prospectus omits material information. Equals zero if the Distributor cannot be held criminally liable when the prospectus is misleading. Equals one-half if the Distributor can be held criminally liable when aware that the prospectus is misleading. Equals one if the Distributor can also be held criminally liable when negligently unaware that the prospectus is misleading.

(3) Criminal accountant

An index of criminal sanctions applicable to the Accountant (or its officers) when the financial statements accompanying the prospectus omit material information. Equals zero if the Accountant cannot be held criminally liable when the financial statements accompanying the prospectus are misleading. Equals one-half if the Accountant can be held criminally liable when aware that the financial statement accompanying the prospectus are misleading. Equals one if the Accountant can also be held criminally liable when negligently unaware that the financial statements accompanying the prospectus are misleading.

Criminal Index The index of criminal sanctions equals the arithmetic mean of: (1) Criminal director; (2) Criminal distributor; and (3) Criminal accountant.

$\underline{\text { Public }}$ The index of public enforcement equals the arithmetic mean of: (1) Supervisor enforcement Index

characteristics index; (2) Investigative powers index; (3) Orders index; and (4) documents; equals one-half if the Supervisor can generally issue an administrative order commanding publicly

$\begin{array}{ccc}0 & 0 & \text { Never } \\ 0 & 0 & \text { Never } \\ 0 & 0 & \text { Never } \\ 1 & 1 & 1986\end{array}$

$\underline{0.25} \quad \underline{0.25}$ $\underline{1986}$

1

0

1986

10

1986

$\underline{1} \quad \underline{0} \quad \underline{1986}$

$1 \quad \underline{0} \quad 1986$

$\underline{0}$

$\underline{1986}$

$1 \quad \underline{0}$

$1 \quad{\underline{0^{*}}}^{*} \quad 1986$

$\underline{0}$
Criminal index. 
Table A5 - Evolution of ownership - 50\% threshold

This table reports evolution of ownership. Ownership is defined as the minimum number of shareholders necessary to pass a threshold of 50\% of cash flow rights, and is computed for all shareholders, for directors alone, and for outsiders. Frequency is the number of companies in which directors and outsiders pass the 50\% threshold alone. Panel A refers to the complete 1900 sample, Panel B to the 1960 sample and Panel C to t-statistics of differences in means between the two samples (1960 minus 1900). Panels D and E report t-statistics of differences of the 1960 sample from the surviving and non-surviving companies in the 1900 sample, respectively. Superscript letters a, b, c indicate significance at 1, 5 and 10 percent levels, respectively.

Panel A: Evolution of ownership, 50\% threshold - complete1900 sample

\begin{tabular}{rrrrrrrr}
\hline & \multicolumn{2}{c}{ All shareholders } & \multicolumn{2}{c}{ Directors } & \multicolumn{2}{c}{ Outsiders } \\
\hline & Mean & Median & Mean & Frequency & Mean & Frequency N. Obs. \\
1900 & 7.02 & 2.50 & 3.15 & 33 & 45.43 & 7 & 40 \\
1910 & 14.05 & 5.00 & 2.15 & 20 & 41.58 & 19 & 40 \\
1920 & 19.81 & 10.00 & 2.38 & 16 & 47.35 & 20 & 37 \\
1930 & 24.46 & 21.00 & 2.92 & 12 & 43.74 & 23 & 36 \\
1940 & 36.84 & 16.50 & 3.40 & 10 & 60.95 & 22 & 32 \\
1950 & 51.63 & 28.00 & 3.86 & 7 & 71.57 & 23 & 30 \\
1960 & 31.67 & 34.00 & 4.80 & 5 & 43.37 & 19 & 24 \\
1970 & 83.68 & 33.00 & 4.00 & 2 & 99.55 & 20 & 23 \\
1980 & 87.00 & 29.00 & 2.00 & 1 & 97.85 & 20 & 22 \\
1990 & 69.14 & 16.00 & 2.00 & 1 & 73.65 & 20 & 21 \\
2000 & 71.75 & 16.50 & 1.50 & 2 & 79.61 & 18 & 20 \\
\hline \hline
\end{tabular}

Panel B: Evolution of ownership, 50\% threshold - 1960 sample

\begin{tabular}{rrrrrrrr}
\hline \hline & \multicolumn{2}{c}{ All shareholders } & \multicolumn{2}{c}{ Directors } & \multicolumn{2}{c}{ Outsiders } \\
\hline & Mean & Median & Mean & Frequency & Mean & Frequency N. Obs. \\
\hline 1960 & 15.85 & 1.00 & 1.28 & 18 & 0.00 & 0 & 20 \\
1970 & 23.55 & 5.50 & 1.33 & 9 & 52.36 & 11 & 20 \\
1980 & 23.11 & 8.00 & 1.83 & 6 & 46.62 & 13 & 20 \\
1990 & 18.25 & 15.00 & 1.00 & 2 & 25.15 & 18 & 20 \\
2000 & 15.35 & 10.00 & 0.00 & 0 & 20.25 & 20 & 20 \\
\hline Mean & 19.18 & & 1.37 & & 32.90 & & \\
\hline \hline
\end{tabular}

Panel C: 1960 vs. 1900 (complete sample) - Tests of means (t-statistics)

\begin{tabular}{lcccccc}
\hline \hline & 1960 vs. 1900 & 1970 vs. 1910 & 1980 vs. 1920 & 1990 vs. 1930 & 2000 vs. 1940 & Overall \\
\hline All shareholders & 0.96 & 0.99 & 0.31 & -1.06 & -1.07 & -0.09 \\
\hline \hline Panel D: 1960 vs. 1900 (survivors alone) - Tests of means (t-statistics) & & & \\
\hline \hline & 1960 vs. 1900 & 1970 vs. 1910 & 1980 vs. 1920 & 1990 vs. 1930 & 2000 vs. 1940 & Overall \\
\hline All shareholders & 0.59 & 0.13 & 0.31 & -1.51 & -1.44 & -0.80 \\
\hline \hline Panel E: 1960 vs. 1900 (non-survivors alone) - Tests of means (t-statistics) & & & \\
\hline \hline & 1960 vs. 1900 & 1970 vs. 1910 & 1980 vs. 1920 & 1990 vs. 1930 & 2000 vs. 1940 & Overall \\
\hline All shareholders & 0.68 & 0.85 & 0.34 & -0.28 & 0.45 & 1.07 \\
\hline \hline
\end{tabular}


Table A6 - Dispersion of ownership - $50 \%$ threshold

This table reports the annual rates of dispersion of ownership over time. Ownership is defined as the minimum number of shareholders necessary to pass the threshold of $50 \%$ of cash flow rights. Dispersion is defined as the change in ownership over the decade. The rates of dispersion are computed for all shareholders, directors alone, and outsiders alone using the formula described in the text. Panel A refers to the 1900 sample, Panel B to the 1960 sample and Panel C reports t-statistics of differences in means across the two samples (1960 minus 1900) for the first four decades of each. Panels D and E report tstatistics of differences of the 1960 sample from the surviving and non-surviving companies in the 1900 sample, respectively. Superscript letters a, b, c indicate significance at 1, 5 and 10 percent levels, respectively.

Panel A: Annual rates of dispersion of ownership, 50\% threshold - complete1900 sample

\begin{tabular}{lcccc}
\hline \hline & All shareholders & Directors & Outsiders & N. Obs. \\
\hline $1900-1910$ & 5.24 & 31.27 & 30.91 & 40 \\
$1910-1920$ & 4.81 & 9.25 & 8.70 & 38 \\
$1920-1930$ & 3.99 & 11.73 & 11.12 & 37 \\
$1930-1940$ & 2.08 & 4.22 & 4.33 & 33 \\
$1940-1950$ & 1.45 & 6.60 & 7.00 & 31 \\
$1950-1960$ & 0.34 & 0.30 & -0.25 & 25 \\
$1960-1970$ & 3.58 & 5.07 & 8.11 & 23 \\
$1970-1980$ & -2.03 & 1.61 & -1.03 & 22 \\
$1980-1990$ & -4.27 & 0.00 & -6.72 & 22 \\
$1990-2000$ & 1.50 & 0.00 & 0.77 & 20 \\
\hline Mean & 2.19 & 8.79 & 8.19 & \\
\hline \hline
\end{tabular}

Panel B: Annual rates of dispersion of ownership, 50\% threshold - 1960 sample

\begin{tabular}{lcccc}
\hline \hline & All shareholders & Directors & Outsiders & N. Obs. \\
\hline $1960-1970$ & 12.84 & 45.94 & 45.00 & 20 \\
$1970-1980$ & 4.47 & 17.08 & 8.38 & 20 \\
$1980-1990$ & 5.50 & 21.05 & 21.73 & 20 \\
$1990-2000$ & -0.07 & 0.10 & 6.96 & 20 \\
\hline Mean & 5.70 & 23.63 & 20.66 & \\
\hline \hline
\end{tabular}

Panel C: 1960 vs. 1900 (full sample) - Tests of Means (t-Statistics)

\begin{tabular}{lccccc}
\hline \hline & First decade & Second decade & Third decade & Fourth decade & Overall \\
\hline All shareholders & $2.42^{\mathrm{b}}$ & -0.11 & 0.46 & -0.85 & 1.02 \\
Directors & 1.12 & 0.75 & 0.91 & 0.65 & 1.56 \\
Outsiders & 1.06 & -0.03 & 1.03 & 0.28 & 1.08 \\
\hline \hline
\end{tabular}

Panel D: 1960 vs. 1900 (survivors only) - Tests of Means (t-Statistics)

\begin{tabular}{lccccc}
\hline & First decade & Second decade & Third decade & Fourth decade & Overall \\
\hline All shareholders & 1.55 & 0.11 & 0.08 & -1.47 & 0.39 \\
Directors & 1.27 & 0.92 & 0.40 & 0.41 & 1.56 \\
Outsiders & 1.21 & 0.22 & 0.50 & -0.07 & 1.06 \\
\hline \hline
\end{tabular}

Panel E: 1960 vs. 1900 (non-survivors only) - Tests of Means (t-Statistics)

\begin{tabular}{lccccc} 
& First decade & Second decade & Third decade & Fourth decade & Overall \\
\hline All shareholders & $2.26^{\mathrm{b}}$ & -0.31 & 0.89 & 0.44 & 1.37 \\
Directors & 0.65 & 0.25 & 1.19 & 0.71 & 1.01 \\
Outsiders & 0.62 & -0.27 & 1.29 & 0.59 & 0.72 \\
\hline \hline
\end{tabular}


Table A7 - The takeover process in the U.K., 1900-1950

The table describes the takeover process in the U.K. in the first half of the twentieth century. Panel A refers to stock acquisitions by companies in the 1900 sample over the period 1900 - 1950, the toehold, the percentage of the target owned after the acquisition and whether the acquisition was a tender offer or a merger. Panel B reports large tender offers from the sample in Hannah (1976), the toehold, the percentage of the target owned after the acquisition, and the means of payment. Panel C reproduces references in the Financial Times to the terms on which offers were made in 22 acquisitions in the first half of the century. This includes four cases from Panel A, 13 from Panel B, and 8 from other acquisitions.

Panel A: Stock acquisitions by companies in the 1900 sample, $1900-1950$

\begin{tabular}{|c|c|c|c|c|c|}
\hline Year & Acquirer & Target & Toehold & $\%$ after & Tender or Merger \\
\hline 1901 & GKN Holdings & Nettlefolds & 0.0 & 100.0 & Merger \\
\hline 1902 & Laird Group & The Mulliner Wigley Co. Ltd & 0.0 & 100.0 & Merger (Private) \\
\hline 1903 & Laird Group & Laird & 0.0 & 100.0 & Merger (Private) \\
\hline 1909 & Reed International & London Paper Mills Co. & 0.0 & 99.9 & Tender \\
\hline 1918 & Marconi (G.E.) & Osram Lamp Works & 0.0 & 100.0 & Merger (Private) \\
\hline 1919 & Laird Group & Midland Railway Carriage and Wagon Co. Ld & 0.0 & 100.0 & Merger (Private) \\
\hline 1919 & Marconi (G.E.) & Peel Conner Telephone Works & 0.0 & 100.0 & Tender \\
\hline 1920 & GKN Holdings & John Lysaght Ltd & 0.0 & 99.8 & Tender \\
\hline 1921 & Tate \& Lyle & Abram Lyle \& Sons & 0.0 & 100.0 & Merger (Private) \\
\hline 1923 & GKN Holdings & Consolidated Cambrian & 0.0 & 96.0 & Tender \\
\hline 1923 & GKN Holdings & D Davis \& Sons & 0.0 & 96.0 & Tender \\
\hline 1923 & Laird Group & Leeds Forge Co. Ld & 0.0 & 99.0 & Tender \\
\hline 1925 & De La Rue & Lamert & 0.0 & 100.0 & (Private) \\
\hline 1929 & Tate \& Lyle & Fairrie \& Co. & 0.0 & 100.0 & Merger (Private) \\
\hline 1930 & GKN Holdings & James Mills Ltd & 0.0 & 100.0 & Merger (Private) \\
\hline 1938 & De La Rue & Davy Gravure & 0.0 & 100.0 & Merger (Private) \\
\hline 1938 & Tate \& Lyle & Macfie \& Sons & 0.0 & 100.0 & Merger (Private) \\
\hline 1947 & GKN Holdings & $49 \%$ of Guest, Keen Williams (+51\%) & 0.0 & 100.0 & Merger (Private) \\
\hline
\end{tabular}

Panel B: Large tender offers (Hannah’s sample) 1919-1939

\begin{tabular}{|c|c|c|c|c|c|}
\hline Year & Acquirer & Target & Toehold & \% after & Means of payment \\
\hline 1919 & Dorman Long & Carlton Iron and Mainsforth Colliery & N. A. & N. A. & \\
\hline 1919 & Guest Keen and Nettlefolds & John Lysaght & 0.0 & 99.8 & Shares \\
\hline 1919 & Lever Bros & Price's Patent Candle Co. & N. A. & N. A. & \\
\hline 1919 & Vickers & Metropolitan Carriage Wagon and Finance & 0.0 & 100.0 & Shares \\
\hline 1920 & Armstrong-Whitworth & Pearson and Knowles Coal and Iron & N. A. & N. A. & \\
\hline 1920 & A. Darracq (S.T.D. Motors after deal) & Sunbeam Motor Car Company & 0.0 & 100.0 & Shares \\
\hline 1920 & Stewarts and Lloyds & Alfred Hickman & 0.0 & 99.9 & Shares \\
\hline 1920 & John Summers & Shelton Iron Steel and Coal Co. & 0.0 & 100.0 & Shares \\
\hline \multirow[t]{2}{*}{1923} & Guest Keen and Nettlefolds & D. Davis and Sons & 0.0 & 96.0 & Shares \\
\hline & & Consolidated Cambrian & 0.0 & 96.0 & Shares \\
\hline 1923 & Richard Thomas & Grovesend Steel \& Tinplate & 0.0 & 100.0 & Shares \\
\hline 1924 & Amalgamated Dental Co. & De Trey & N. A. & N. A. & \\
\hline \multirow[t]{2}{*}{1925} & Distillers & Buchanan-Dewar & 0.0 & 99.9 & Shares \\
\hline & & John Walker \& Sons & 0.0 & 100.0 & Shares \\
\hline 1925 & Lever Bros & British Oil \& Cake Mills & 0.0 & 100.0 & All Cash \\
\hline 1927 & British Match Corporation & Bryant \& May & 0.0 & 99.0 & Shares \\
\hline \multirow[t]{4}{*}{1928} & Associated Electrical Industries & British Thomson-Houston & 0.0 & 100.0 & Shares \\
\hline & (International General Electric) & Metropolitan Vickers Electrical & & & \\
\hline & & Ferguson Pailin Ltd & 0.0 & 100.0 & All Cash \\
\hline & & Edison Swan Electric & 0.0 & 92.7 & All Cash \\
\hline 1928 & Inveresk Paper & United Newspapers (Daily Chronicle Invt. Corp.) & N. A. & N. A. & \\
\hline 1928 & J. Sears \& Co (Trueform Boot Co) & Freeman Hardy \& Willis & 0.0 & 99.0 & All Cash \\
\hline 1928 & Turner \& Newall & Bells United Asbestos & 0.0 & 100.0 & Shares \\
\hline 1928 & Watney Combe Reid & Huggins \& Co. & 0.0 & 99.0 & All Cash \\
\hline 1929 & Barclay, Perkins and Co. & Style \& Winch & 0.0 & 99.0 & Shares \\
\hline \multirow[t]{2}{*}{1929} & Unilever & Lever Bros & 0.0 & 100.0 & Shares \\
\hline & & Margarine Union & & & \\
\hline \multirow[t]{2}{*}{1930} & Barry \& Staines Linoleum & Barry Ostlere \& Shepherd & 0.0 & 100.0 & Shares \\
\hline & & Linoleum Manufacturing & 0.0 & 100.0 & Shares \\
\hline 1930 & Taylor Walker & Cannon Brewery & 0.0 & 98.0 & Shares \\
\hline 1933 & Charrington & Hoare \& Co & 0.0 & 100.0 & Shares \\
\hline \multirow[t]{2}{*}{1934} & Ind Coope \& Allsopp & Ind Coope & & & \\
\hline & & Allsopp \& Co & 0.0 & 100.0 & Shares \\
\hline \multirow[t]{2}{*}{1935} & Hawker Siddeley & Hawker Aircraft & 0.0 & 51.1 & Shares \\
\hline & & Armstrong Whitworth Developments & 0.0 & 100.0 & Shares \\
\hline 1936 & Stewarts and Lloyds (United Tube Holdings) & British Mannesmann Tube Co. & 0.0 & 99.0 & Shares \\
\hline 1937 & Distillers & Booth's Distilleries & 0.0 & 97.8 & All Cash \\
\hline 1937 & Imperial Chemical Industries & Salt Union & 0.0 & 90.0 & Shares \\
\hline 1938 & Associated Portland Cement Manufacturers & Alpha Cement & 0.0 & 74.0 & Shares \\
\hline 1938 & Beechams Pills & Eno Proprietaries & 0.0 & 97.0 & Shares \\
\hline 1939 & Stewarts \& Lloyds & Stanton Ironworks Co & 0.0 & 100.0 & Shares \\
\hline
\end{tabular}


Panel C: References in the Financial Times (FT) to acquisitions in the first half of the $20^{\text {th }}$ century

\begin{tabular}{lll}
\hline \hline Year & Acquirer & Target \\
\hline 1919 & Vickers & W. T.
\end{tabular}

W. T. Glor

Quote

"Shareholders of W. T. Glover and Company, Ltd., the electric wire and cable manufacturers, of Trafford Park, Manchester, have received a circular from the Chairman, accompanying the annual report, published in another column, in which an offer from Vickers, Ltd., to acquire the shares of Glover and Company is set out. The circular is as follows: 'The directors have recently been approached on behalf of Vickers, Ltd., with a view to that company acquiring the controlling interest in this company by means of an exchange of shares. As the result of negotiations, Vickers, Ltd., have now agreed with myself (as Chairman of the Board acting as trustee for the shareholders) to purchase the shares of this company from the respective holders such of them as think fit to adopt the agreement, at the following prices: For every Preference $£ 1$ share the sum of $17 \mathrm{~s} 6 \mathrm{~d}$ in cash; For every four $£ 1$ Ordinary shares five fully-paid $£ 1$ Ordinary shares of Vickers, Ltd. ... Your directors (among whom are substantial holders of the company's Preference and Ordinary shares) are of the opinion that the terms of the sale are favourable to the shareholders, and will agree to sell their own shares accordingly. If you propose to take advantage of this offer it is necessary that you should sign ... Yours faithfully, A. L. Ormrod, Chairman, W. T. Glover and Co., Ltd." FT Friday 2 May 1919

"To the ordinary shareholders of John Lysaght, Ltd. Dear Sir (or Madam), As you will have seen from the preliminary announcement published in the Press by the authority of your Directors, an offer has been received from Guest, Keen and Nettlefolds, Limited, for the purchase of the Ordinary shares in John Lysaght, Limited. The offer to the shareholders of your Company is of three Ordinary shares and four $5 \%$ Cumulative Second Preference shares (free of income tax) ranking pari passu with the present issue of this class of shares in Guest, Keen and Nettlefolds, Limited. ... The offer has been unanimously accepted by the Directors of your company for the whole of their individual shares, and they have no hesitation in recommending its acceptance to the shareholders." FT Monday 19 January 1920.

1920 Lever Brothers Niger Company

"The Directors of the Niger Company have received an offer from Lever Brothers, Port Sunlight, to purchase all the issued Ordinary shares in the Company at $£ 610$ s each, payable in cash on or before $1^{\text {st }}$ July next, together with interest on the price at the rate of $7 \%$ per annum

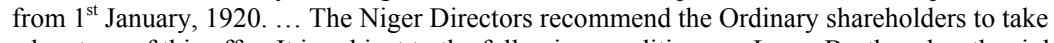
advantage of this offer. It is subject to the following conditions ... Lever Brothers has the right to take any shares in respect of which its offer may be accepted, but reserves the right to cancel the agreement altogether if acceptances for at least $75 \%$ of the issued Ordinary shares are not received within the stipulated time." FT Monday 26 January 1920

1920 John Summers and Sons

Shelton Iron Steel and Coal Company

\section{Sunbeam Motor Car} Company

(S.T.D. Motors after deal)

1920
Stewart and
Lloyds

1923

GKN Holdings

Consolidated Cambrian
Collieries

Alfred Hickman

D Davis \& Sons

1923

\begin{abstract}
London and
Lancashire
\end{abstract}

Insurance Co.

British Fire Insurance
Company

British Fire Insurance
Company

"The Shelton Iron Steel and Coal Company intimates that negotiations have taken place between some of the large shareholders and John Summers and Sons, Ltd., which have resulted in the acquisition by the latter of the majority of the Shelton shares. The price is $£ 15 \mathrm{~s}$ per share, payable as to $£ 1$ in Seven and a half per cent. Cumulative Preference shares of John Summers and Sons and $5 \mathrm{~s}$ in cash. Arrangements have been made by which similar terms will be offered in due course to the whole of the Shelton shareholders." FT Tuesday 24 February 1920

"The official announcement that the Directors of A. Darraq and Company (1903) and the Sunbeam Motor Car Company have concluded an agreement, subject to ratification by the respective shareholders, for an amalgamation of their extensive interests is of more than ordinary importance as presaging the materialisation of the greatest combine that has been negotiated in the motor industry in this country. ... The proposed amalgamation will take the form of an exchange of shares on an equal basis - namely, that the Sunbeam shareholders will, in exchange for their present holding, receive an equal number of shares in the Darraq Company..." FT Wednesday 9 June 1920

"The Directors of Alfred Hickman, the well-known Midland firm of steel and iron manufacturers, yesterday issued to their shareholders particulars of the offer for the Ordinary and Cumulative Participating Preference shares which they have received from Stewarts and Lloyds, together with a form of acceptance. The circular sets forth that the directors have themselves accepted the offer, and they strongly recommend its acceptance by the shareholders. It is embodied in a provisional agreement of the $21^{\text {st }}$ August, 1920, which is conditional on its approval by holders of at least 80 per cent of the shares mentioned on or before $15^{\text {th }}$ September "FT Tuesday 24 August 1920

"An important deal is involved in the offer of Guest Keen and Nettlefolds to the shareholders of D Davis and Sons and of the Consolidated Cambrian Collieries, both of which own extensive colliery undertakings in South Wales. For each five Ordinary $£ 1$ shares of the Consolidated Cambrian Guest Keen offer two Ordinary, and for every five $5 \mathrm{~s}$ Ordinary shares in D Davis and Sons Guest Keen offer one Ordinary.... Acceptance of the offer is strongly recommended by both directorates, who have decided to accept it as regards their own individual holdings. $90 \%$ of the Ordinary shares of each company must accept the offer by $30^{\text {th }}$ November or it may be withdrawn. If the deal should go through, as no doubt it will, Guest Keens will have a coal output of at least 7,000,000 tons per annum. The attraction to Davis and Cambrian shareholders is that they will secure an interest in an undertaking which by reason of its varied interests has achieved uniformly good results and has weathered the trade depression with conspicuous success." FT Thursday 15 November 1923

"The directors of the British Fire Insurance Co. have issued a circular giving details of the offer made by the London and Lancashire Insurance Co. for the purchase of British Fire shares.... Payment to be made as follows ... All the directors of the British Fire have decided to accept the offer as concerns their own holdings, and they recommend the offer to the acceptance of all other shareholders. ... the offer is conditional upon acceptance by the holders of at least $85 \%$ of the issued share capital of British Fire" FT Friday 23 March 1923

"An official intimation is made that a circular is about to be issued by the directors to the shareholders in the Leeds Forge Company recommending the acceptance of an offer which has been made by Cammell Laird and Co. to exchange one $£ 1$ Ordinary share of Cammell Laird for every two $£$ ' Ordinary in the Leeds Forge and one Ordinary of Cammell Laird for one $£ 1$ Seven \% Cum. Preference of the Leeds Forge" FT Saturday 23 June 1923 p. 5 
Grovesend Steel \& Tinplate

\section{Distillers}

Buchanan-Dewar

John Walker \& Sons

1928

Union Cold

Storage Company

London Central Markets

Cold Storage Company

1928 Amherst Estates

St. Ives Rubber Estates

1928

Watney Combe

Reid

1928

J. Sears \& Co

1928

Manchester

Collieries

1928

Scottish Drapery

Corporation

1928

Turner \& Newall

Bells United Asbestos

1935 Allied

Ironfounders

1935

Hawker Siddeley

Armstrong Whitworth

1938 Beechams Pills
Hawker Aircraft

Developments

Freeman Hardy and Willis

Andrew Knowles and Sons

\section{J. R. Allan}

Aga Heat

Eno Proprietaries

"Further particulars of the amalgamation in the tinplate trade, which was confirmed by our Swansea correspondent in yesterday's FT, show that Richard Thomas and Co. have offered to take over (a) $80 \%$ of the shares of the Grovesend Company, or (b) the whole of the shares of the Company. So far as the $80 \%$ is concerned it is certain that the deal will be completed. With regard to the other $20 \%$ it is regarded as a practical certainty that the holders will agree. Meanwhile, a circular has been issued to the $20 \%$ stating that the holders of $80 \%$ of the shares have accepted and recommending holders of the other $20 \%$ to accept. The terms are that the Ordinary shares of the Grovesend Company shall be exchanged for the Ordinary shares of Richard Thomas and Co., in part payment, plus a very substantial cash payment to the holders of Grovesend Company." FT Monday 15 October 1923

"The Chairman (of Distillers) in proposing the special resolution, said: .... Before we can carry out the terms of the provisional agreements with the other two companies shareholders it will be necessary to amend our present articles of association Unfortunately, this cannot be done without obtaining the sanction of the court" ... "If the necessary number of shareholders accept the offer, and we are asking for $90 \%$ of the shareholders of the other two companies to accept, but with power to accept a smaller number, not however less than $75 \%$..." FT Monday 9 March 1923

"Shareholders of London Central Markets Cold Storage Company are notified that a provisional agreement has been made for amalgamation... In a circular the directors ... point out that they have agreed to take $6 \%$ Cumulative Preference shares in respect of their holdings in preference to the cash offer ... and recommend shareholders to accept the offer" FT Friday 21 September 1928

"The directors of the St. Ives Rubber Estates announce that ... after negotiations with the directors of the Amherst Estates (Selangor) Rubber Company, they have entered into a draft agreement with that company. The terms of the amalgamation, which is subject to the approval of the shareholders of both companies, are the issue of 250,000 fully paid 2s Amherst shares to the St. Ives shareholders. They have been mutually agreed upon by the directors of both companies as fair and equitable to all parties." FT Monday 24 September 1928

"Shareholders of Huggins and Co., the West End brewers, have been informed than an offer has been made by a well-known brewery company to purchase their holdings at $£ 58 \mathrm{~s} 6 \mathrm{~d}$ per share. The offer is conditional upon acceptance by $76 \%$ of the holders... The directors intimate that they have accepted the offer and strongly recommend shareholders to accept" FT Saturday 13 October 1928

"The Financial Times is officially informed that an offer for the purchase of Freeman Hardy and Willis Preferred Ordinary shares at the price of $£ 36$ s and for the Deferred Ordinary at $£ 7$ $7 \mathrm{~s} 6 \mathrm{~d}$ net per share has been received. The directors, who have themselves accepted the offer, recommend same to shareholders." FT Monday 15 October 1928

"The terms are now available... In exchange for the issued share capital of 750,000 fully-paid $£ 1$ shares, Andrew Knowles and Sons will receive£706,500 in shares of the new company... The circular adds that in view of the satisfactory financial position and earning capacity... the directors are of opinion that the amalgamation will prove of advantage to all the parties concerned, and recommend the proposals which will be submitted at a meeting..." FT Tuesday 20 November 1928

"An offer has been made by the Scottish Drapery Corporation to purchase the Ordinary shares of J. and R. Allan, drapers and silk members of Edinburgh, at $27 \mathrm{~s}$ per share... The offer is conditional upon acceptance by $90 \%$ of the holders... The Ordinary shares (of J. R. Allan) are quoted on Edinburgh at 25s." FT Saturday 24 November 1928

"For each Bell's Ordinary held shareholders will receive in exchange one Turner and Newall Ordinary of $£ 1 \ldots$... FT Tuesday 27 November 1928 "Your directors are of the unanimous opinion that the offer made by Turner and Newall, Ltd., is equitable, and your Board have no hesitation in recommending it for acceptance... Your Board have been gratified by the receipt of an exceptionally large number of proxies, representing approximately $75 \%$ of the issued shares of the company, in support of the present recommendations." FT Friday 7 December 1928

"An offer has been made by the directors of Allied Ironfounders, of which Mr. A. W. Steven is chairman, for the whole of the issued share capital of Aga Heat, manufacturers of heat and cooking appliances. The terms offered are one fully paid £1 Ordinary of Allied Ironfounders for every five fully-paid 5s shares in Aga Heat... The offer, which is recommended by the directors, , is conditional upon acceptance by holders of not less than $90 \% \ldots$ Mr. J. E. V. Jobson, the chairman, has accepted a seat on the Board of Allied Ironfounders." FT Thursday 11 July 1935

"The subscription list will open and close on Tuesday next for the issue of Hawker Siddeley Aircraft Company of 1,000,000 Five \% Cumulative Preference shares of $£ 1$ each at par and $1,000,000$ Ordinary shares of $5 \mathrm{~s}$ each at $15 \mathrm{~s}$ per share. As previously reported in The Financial Times, the company is acquiring the whole of the issued Ordinary share capital of Armstrong Whitworth Developments and 50\% of the issued share capital of Hawker Aircraft ... The issue will be advertised at the coming weekend and prospectuses will be available after 3.30 today from the company's bankers" FT Friday 12 July 1935

"Formal offer is now made by Beecham Pills to acquire the Ordinary shares of Eno Proprietaries. As announced bin The Financial Times last Wednesday, holders of Eno Ordinary are invited to exchange their shares on the basis of five $2 \mathrm{~s} 6 \mathrm{~d}$ Deferred of Beechams for every eight $5 \mathrm{~s}$ shares held. The offer, which is unanimously recommended by the directors of Eno Proprietaries, is conditional upon acceptance by at least $90 \%$, or such lower percentage as Beechams may agree to accept." FT Saturday 8 October 1938 